\title{
Phenotype diversity and phylogeny of selected Scytonema-species (Cyanoprokaryota) from SE Brazil
}

\author{
Jiří KomÁReK ${ }^{1}$, Celia L. SAnt'AnNA ${ }^{2}$, Markéta BohunickÁ ${ }^{1}$, Jan MareŠ ${ }^{1}$, Guilherme \\ S. HENTSCHKE ${ }^{2}$, Janaina RigONATO ${ }^{3} \&$ Marli F. FIORE ${ }^{3}$
}

${ }^{1}$ Academy of Sciences of the Czech Republic, Institute of Botany, Dukelská 135, CZ - 37982 Treboñ, and University of South Bohemia, Faculty of Science, Department of Botany, Branišovská 31, CZ-37005 České Budějovice, Czech Republic

${ }^{2}$ Institute of Botany, Nucleus of Phycology, Caixa Postal 4005, BR-01051 São Paulo, SP, Brazil

${ }^{3}$ University of São Paulo, Center of Nuclear Energy in Agriculture, Avenida Centenário 303, BR 13416-000 Piracicaba, SP, Brazil

\begin{abstract}
Members of the genus Scytonema belong to prominent components of microflora of tropical and subtropical soils, but their diversity and taxonomic classification is still little known. Molecular analyses of isolated strains, but also the morphological and ecological examination of natural populations are important for the starting revisions. Here we present phenotype characteristics of fourteen morphotypes of the cyanobacterial genus Scytonema from the SE Brazil, mostly from the state São Paulo and from the Atlantic Rainforest (ecosystem of "Mata Atlântica"). The populations of studied Scytonema species are ecologically significant, as they hold the dominant position in the microvegetation communities of lateritic and forest soils and of stony substrates (less frequently also aquatic forms). Species commonly distributed throughout the tropical regions (such as $S$. guyanense, $S$. javanicum, $S$. stuposum), as well as the types with restricted geographic distribution in $\mathrm{S}$ America are included in the study. Two new species from a little known subgenus Myochrotes, in which the cultivation is difficult, are described: S. papillicapitatum Sant'Anna et KomÁrek and S. chorae Sant'AnNa et KomÁrek. Our analyses support the principle of congruency of morphological characters with phylogenetic position of the studied species.
\end{abstract}

Key words: Cyanobacteria, Scytonema, taxonomy, new species, polyphasic approach, ecology, Brazil (SP)

\section{INTRODUCTION}

The statement that cyanobacteria have a cosmopolitan distribution is valid only for a few types from this group of organisms and most species have specific ecological demands according to our results. In consequence, cyanobacterial species typically occur in ecologically specific and often also geographically restricted habitats. The genus Scytonema is generally considered to be cosmopolitan, however, it contains numerous species, which grow only in tropical and ecologically distinctly delimited habitats, such as lateritic soils, dripping rocks and reservoirs with water vegetation. The knowledge of their morphological variability is important for their identification, but still little known, and their supposed restricted areas of distribution require thorough revision. We have found several Scytonema populations in the important global biodiversity hotspot area (cf. MYERs et al. 2000) in the tropical/subtropical Atlantic Rainforest ("Mata Atlântica") during our studies of cyanobacteria in the last years in the state of São Paulo (SE Brazil). The observed populations formed a substantial component of the abundant subaerophytic microphyte vegetation of this ecosystem.

The traditional taxonomic description of the genus Scytonema was summarized by GeITLER (1932), Desikachary (1959), Starmach (1966), Bourrelly (1970) and KomÁreK \& Anagnostidis (1988), but the modern revision based on polyphasic approach is still in the beginning. As follows from the current molecular data, Scytonema is polyphyletic (similarly to other traditional cyanobacterial genera, see e.g., BOYER et al. 2002; BerRENDERo et al. 2008; ZAPOMĚLOVÁ et al. 2011, etc.) and it will evidently be divided into several generic entities (BoHUNickÁ et al. 2012). The genus sensu stricto has to be based on the type species $S$. hofmannii C. Agardh ex Bornet et Flahault, morphologically characterized by cylindrical trichomes along the whole length, more or less quadratic cells in the main trichomes, and relatively narrow sheaths (КомÁREK \& AnAGnostidis 1988). A conspicuous part of the genus, distinctly different in terms of morphology from the former typical group, is the subg. Myochrotes, which has, however, not yet been sequenced. This applies also to the genus Petalonema, sometimes also included into Scytonema. Both these taxa (genera) seem to be morphologically more related one to another than to 
the typical Scytonema (comp. Table 3). Brasilonema is a recently described genus (FIORE et al. 2007) that is morphologically similar to Scytonema, but was clearly separated from Scytonema after polyphasic evaluation. Moreover, there are several other characteristic morphological groups within Scytonema sensu lato that can be separated by careful examination, and we comment these groups in the results of our study.

The modern cyanobacterial taxonomy is mainly based on the polyphasic approach (JOHANSEN \& CASAMATtA 2005; KomÁReK 2010), in which the molecular sequencing and phylogenetic comparisons belong to the basic techniques. Unfortunately, Scytonema species are among those cyanobacteria (together with numerous other genera) which frequently resist isolation into cultures. Thus, the transfer of our studied populations into monospecific cultures was sometimes difficult and we were able to support our taxonomic decisions by molecular sequencing only in few cases. Although the molecular evaluation of species within the genus Scytonema is apparently essential, we consider a good characterization of the variation in different morphological markers to be equally important for the overall biological knowledge of this group of cyanobacteria. Nowadays, the importance of cyanobacteria in the ecosystems is increasingly acknowledged and the correct identification of the dominant populations in common habitats (such as various types of soils, forests, lakes, reservoirs, etc.) is particularly desirable according to recognizable markers. Therefore, the knowledge of morphological variability of various eco- and morphotypes (and species) in natural populations is extremely beneficial.

In this study, we present a thorough phenotypic analysis of the dominant Scytonema populations from one of the most important hotspots of biodiversity of the world, Atlantic Rainforest in SE Brazil, supplemented with an evolutionary reconstruction showing phylogenetic position of some of the studied Scytonema species.

\section{Material, Localities and Methods}

The studied material was collected from different localities in São Paulo and Minas Gerais States, Brazil, mainly in Atlantic Rainforest (Table 1). Majority of the samples were collected from terrestrial habitats, where they grew on periodically or irregularly wetted surface; only few types originated from water biotopes. Details are described in the individual species. Terrestrial samples were collected scraping the substrate (soil, rock, concrete and wood), then kept in dried state in paper envelopes. The aquatic material was collected passing the plankton net among the macrophytes.

The morphological study was carried out using optical microscopes, type Leitz Dialux 22 and Olympus BX 51, equipped with Nomarski DIC and brightfield optics. The identification of taxa was done based on at least 20 specimens of each population. The species were documented by drawings and digital photographs. First subsample of each of the samples was preserved in formaldehyde and held in the Herbarium of the Institute of Botany (SP), Brazil (Table 1). In dried samples, the second subsample was placed into a liquid Z8 medium (КотAI 1972) to recover from a dried state for $24 \mathrm{~h}$. The Scytonema species were then isolated into unicyanobacterial clonal strains using dilution plating on agar-solidified Z8 medium. Cultures are maintained in Z8 agar slants in ambient light and temperature of $16{ }^{\circ} \mathrm{C}$ and are available at Culture Collection of Autotrophic Organism (CCALA), Institute of Botany of the AS CR, Třeboň, Czech Republic and Collection of the Botanical Institute, São Paulo, Brazil.

Molecular and phylogenetic analyses. Total genomic DNA of Scytonema strains was isolated from biomass dried over silica gel and pulverized using Retsch MM200 laboratory mill with wolfram carbide beads ( 3 minutes, $30 . \mathrm{s}^{-1}$ ), following the modified xanthogenate-SDS buffer extraction protocol with addition of 3\% PVPP and PEG- $\mathrm{MgCl}_{2}$ precipitation (YILMAZ et al. 2009). Partial 16S rRNA gene and the adjacent ITS region were amplified following BOYER et al. (2001), using 10 ng of template DNA and $2 \times$ conc. Plain PP Master Mix (Top Bio, Czech Republic). The PCR products were cloned using the standard pGEM ${ }^{\circledR}-\mathrm{T}$ Easy vector system, and sequenced on ABI PRISM 3130xl automated sequencer with plasmid primers T7f (5'-TAA TAC GAC TCA CTA TAG GG-3') and SP6r (5'-TAT TTA GGT GAC ACT ATA G-3'). Obtained sequences were aligned by MAFFT v. 6 (KATOH et al. 2009) together with 141 OTUs derived from GenBank, representing the current variability of the family Scytonemataceae and the whole group of heterocytous cyanobacteria, and two outgroup taxa (Gloeobacter violaceus PCC 7421 and Chroococcidiopsis thermalis PCC 7203). The resulting alignment was corrected manually to remove ambiguous gap regions. The final phylogenetic tree was constructed by the ML method via PhyML v. 3.0 (GuIndon et al. 2010) run on the MetaCentrum computer cluster (www.metacentrum.cz), using the generalized time-reversible (GTR) substitution model with discrete gamma distribution in six categories. The gamma shape parameter $\alpha$ as well as the proportion of invariable sites were estimated from the data set. The GTR $+\Gamma+$ I model was chosen by Modeltest 3.7 (PosadA \& CRANDAll 1998) using Akaike information criterion (AIC). One thousand bootstrap replicates were executed to evaluate the relative support of branches. A maximum parsimony (MP) analysis was run using the same alignment as previously: one hundred replicate searches with starting tree obtained by random stepwise addition were performed using the tree bisection-reconnection (TBR) branch swapping algorithm in TNT v. 1.1. (GolobofF et al. 2008); one thousand nonparametric bootstrap replications were run with default settings to evaluate the relative branch support. All bases and base changes were weighted equally, and gaps were coded as missing data. A neighbor-joining analysis using HKY model upon default parameters with 1000 bootstrap replicates was run via SeaView v. 4 (Gouy et al. 2010). Phylogenetic trees were drawn and edited using FigTree v. 1.3. (http://tree.bio. ed.ac.uk/software/figtree/). The sequences of strains CCIBt were deposited in NCBI GenBank under accession numbers KC682101-KC682103 and CCALA strains under accession numbers HF911525-HF911528. 
Table 1. Sampling localities, coordinates and herbarium numbers of the examined material of Scytonema-species from SE Brazil; (N.A.) not available.

\begin{tabular}{|c|c|c|c|c|}
\hline Locality & Coordinates & Date & Species & Herbarium number \\
\hline \multirow{4}{*}{$\begin{array}{c}\text { Cantareira Ridge (Horto } \\
\text { Florestal) }\end{array}$} & \multirow{4}{*}{$\begin{array}{l}23^{\circ} 27^{\prime} 35^{\prime \prime} \mathrm{S} \\
46^{\circ} 37^{\prime} 52^{\prime \prime} \mathrm{W}\end{array}$} & \multirow{4}{*}{$10 / 1996$} & S. guyanense & \multirow{4}{*}{ SP 427934} \\
\hline & & & S. javanicum & \\
\hline & & & S. ocellatum & \\
\hline & & & S. chorae & \\
\hline \multirow{6}{*}{$\begin{array}{c}\text { Campos do Jordão } \\
\text { Municipality } \\
\text { (Horto Florestal) }\end{array}$} & & $11 / 2002$ & S. guyanense & N.A. \\
\hline & $\begin{array}{l}22^{\circ} 50^{\prime} 06^{\prime \prime} \mathrm{S} \\
45^{\circ} 37^{\prime} 18^{\prime} \mathrm{W}\end{array}$ & $11 / 2002$ & S. javanicum & SP427509 \\
\hline & \multirow{4}{*}{$\begin{array}{l}22^{\circ} 58^{\prime} 30, ' \mathrm{~S} \\
45^{\circ} 38^{\prime} 44^{\prime \prime} \mathrm{W}\end{array}$} & \multirow{4}{*}{$11 / 2002$} & S. ocellatum & $\begin{array}{l}\text { SP } 427507 \\
\text { SP } 427933\end{array}$ \\
\hline & & & Scytonema sp. & \multirow{2}{*}{ SP 427935} \\
\hline & & & S. cf. bohneri & \\
\hline & & & S. guyanense & SP 427938 \\
\hline \multirow{3}{*}{$\begin{array}{l}\text { Ecological Station } \\
\text { Juréia-Itatins }\end{array}$} & \multirow{3}{*}{$\begin{array}{l}24^{\circ} 31^{\prime} 48^{\prime \prime} \mathrm{S} \\
47^{\circ} 11^{\prime} 27^{\prime \prime} \mathrm{W}\end{array}$} & \multirow{3}{*}{ 09/2002 } & S. guyanense & N.A. \\
\hline & & & S. hyalinum & N.A. \\
\hline & & & S. cf. longiarticulatum & SP 427936 \\
\hline \multirow{3}{*}{$\begin{array}{l}\text { Ubatuba Municipality } \\
\text { (Gruta que Chora) }\end{array}$} & \multirow{3}{*}{$\begin{array}{l}23^{\circ} 244^{\prime} 05^{\prime \prime} \mathrm{S} \\
45^{\circ} 0{ }^{\prime} 07^{\prime \prime} \mathrm{W}\end{array}$} & $01 / 1986$ & S. chorae & SP 188482 \\
\hline & & $11 / 2002$ & S. javanicum & SP 427934 \\
\hline & & $11 / 2004$ & S. crispum & N.A. \\
\hline $\begin{array}{c}\text { Onda Verde } \\
\text { (Santa Irene Stream) }\end{array}$ & $\begin{array}{l}20^{\circ} 38^{\circ} 40^{\prime \prime} \mathrm{S} \\
49^{\circ} 18^{`} 29^{\prime \prime} \mathrm{W}\end{array}$ & $11 / 2002$ & S. guyanense & SP 427941 \\
\hline \multirow{3}{*}{$\begin{array}{l}\text { Ecological Station of } \\
\text { Paranapiacaba }\end{array}$} & \multirow{3}{*}{$\begin{array}{l}23^{\circ} 46^{\prime} 43^{\prime \prime} \mathrm{S} \\
46^{\circ} 18^{\prime} 18^{\prime \prime} \mathrm{W}\end{array}$} & \multirow{2}{*}{$11 / 2004$} & S. hyalinum & \multirow{2}{*}{ SP 427939} \\
\hline & & & S. cf. bohneri & \\
\hline & & $11 / 2004$ & S. stuposum & N.A. \\
\hline $\begin{array}{l}\text { Mogi Guaçu } \\
\text { Municipality } \\
\text { (Jacaré Lake) }\end{array}$ & $\begin{array}{l}22^{\circ} 22^{\prime} 15^{\prime \prime} \mathrm{S} \\
46^{\circ} 56^{\prime} 16^{\prime \prime} \mathrm{W}\end{array}$ & $06 / 2002$ & S. papillicapitatum & SP 188495 \\
\hline Viçosa Municipality & $\begin{array}{l}20^{\circ} 45^{\prime} 26^{\prime \prime} \mathrm{S} \\
42^{\circ} 52^{\prime} 30^{\prime \prime} \mathrm{W}\end{array}$ & $06 / 2004$ & S. arcangelii & SP 427940 \\
\hline Bertioga Municipality & $\begin{array}{l}23^{\circ} 48^{\prime} 12^{\prime \prime} \mathrm{S} \\
46^{\circ} 08^{\prime} 81^{\prime \prime} \mathrm{W}\end{array}$ & $11 / 2002$ & S. schmidtii & SP 371429 \\
\hline \multirow{4}{*}{$\begin{array}{l}\text { State Park of } \\
\text { Ilha do Cardoso }\end{array}$} & \multirow{4}{*}{$\begin{array}{l}25^{\circ} 04^{\prime} 08^{\prime \prime} \mathrm{S} \\
47^{\circ} 55^{\prime} 88^{\prime \prime} \mathrm{W}\end{array}$} & \multirow{2}{*}{$06 / 2010$} & S. schmidtii & SP 401438 \\
\hline & & & S. hyalinum & SP 427937 \\
\hline & & 06/1989 & \multirow[t]{2}{*}{ S. chorae } & $\begin{array}{l}\text { SP } 187567 \\
\text { SP } 238953 \\
\text { SP } 238956 \\
\text { SP } 238973\end{array}$ \\
\hline & & $04 / 1988$ & & SP 238978 \\
\hline Nucleous Santa Virginia & $\begin{array}{l}23^{\circ} 20 ' 35^{\prime \prime} \mathrm{S} \\
45^{\circ} 08^{\prime} 17^{\prime \prime} \mathrm{W}\end{array}$ & $02 / 2010$ & S. cf. bohneri & SP 401449 \\
\hline
\end{tabular}




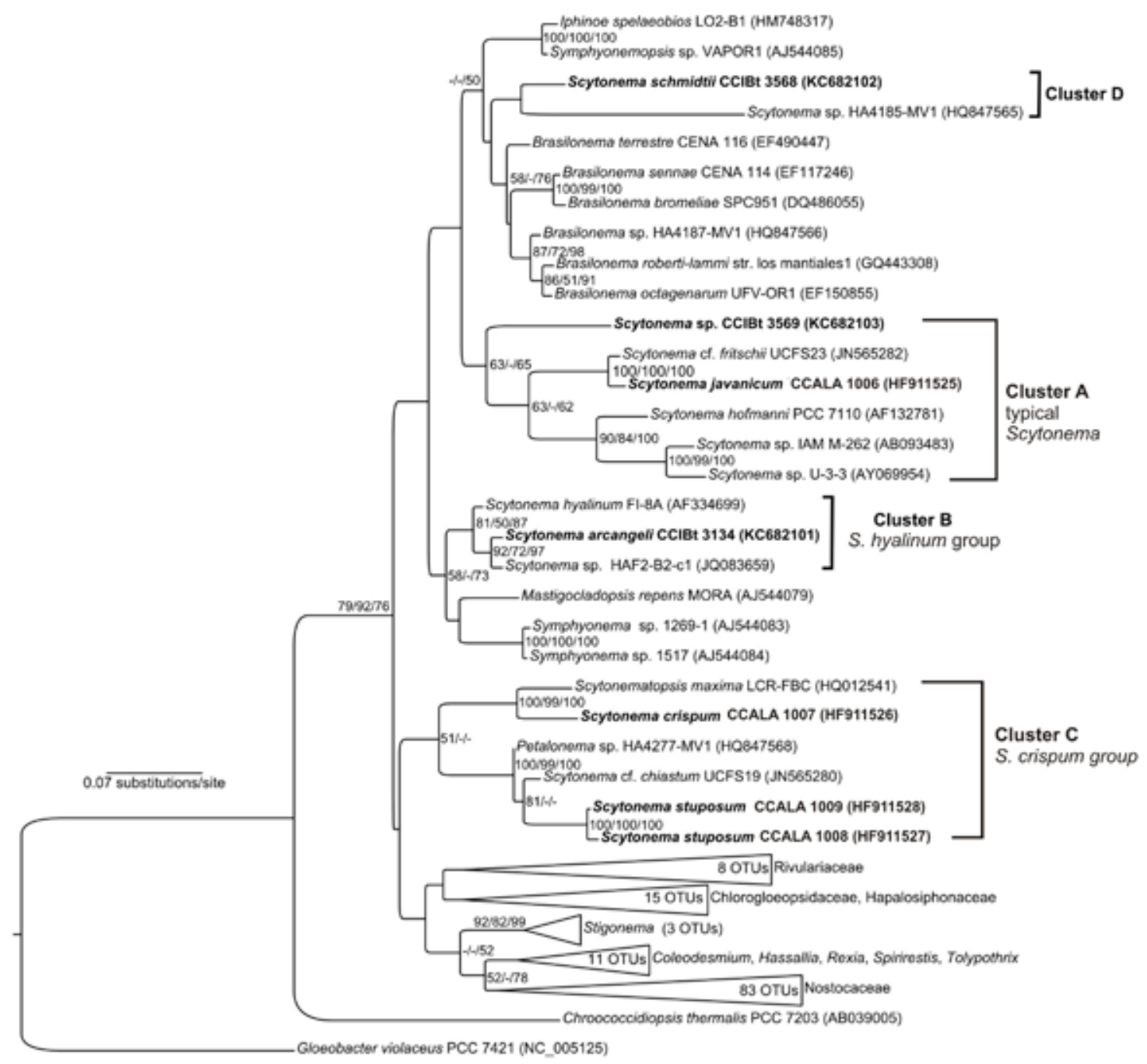

Fig. 1. Maximum likelihood (ML) phylogenetic tree inferred from 148 sequences (partial 16S rDNA) representing the current GenBank data on heterocytous cyanobacteria, focusing on the family Scytonemataceae. Bootstrap values (1000 replicates for ML, maximum parsimony - MP, and neighbour-joining - NJ) equal to 50 or higher are given at the nodes in this form: ML/MP/NJ. Our original sequences are printed in bold font. In the tree, strains of the genus Scytonema formed four separate clusters (A-D) correspoding to the respective morphological groups A-D described in the text.

\section{RESUlts}

We have analysed 28 populations from natural samples (mainly from aerophytic habitats), and also 7 isolated strains. From this material, we have recognized 13 Scytonema-taxa on the specific level according to the phenotype criteria, presented in Tables 2, 3. Characters of Brazilian specimens are described in the paragraph designated "Description".

\section{Phylogenetic analysis}

The final alignment of the 16S rRNA gene was 1320 bp long. Within the alignment, 750 sites $(56.8 \%)$ were conservative, and 336 sites $(25.5 \%)$ were parsimony informative. A single tree $(-\operatorname{lnL}=18728.37)$ was recovered in the ML analysis, while 288 most parsimonous trees $(1=3,313)$ were collapsed into a strict consensus tree. In all trees obtained, included sequences of the family Scytonemataceae formed four lineages (Fig. 1): (A) the cluster including the type species $S$. hofmanni, Scytonema sp. CCIBt 3569 and $S$. javanicum CCALA 1006 from Brazil; (B) the group of S. arcangelii (Brazil) and S. hyalinum; (C) a separate lineage of three Scytonema isolates from Brazil ( $S$. crispum CCALA 1007, S. stuposum CCALA 1008 and CCALA 1009) together with possible Petalonema sp. from Hawaii, S. cf. chiastum and Scytonematopsis maxima (both from the New Zealand); (D) the cluster consisiting of Scytonema schmidtii CCIBt 3568 from Brazil and Scytonema sp. isolated from a wet wall in Hawaii - this group forms a sister clade to Brasilonema in our tree. Other genera and families (Rivulariaceae, Hapalosiphonaceae, Nostocaceae, etc.) clustered separately from the family Scytonemataceae, 
with exception of several representatives of truebranching genera, which were closely related to Brasilonema (Symphyonemopsis, Iphinoe) and the $S$. hyalinum lineage (Mastigocladopsis, Symphyonema). The results consistently showed the traditional family Scytonemataceae and the genus Scytonema itself to be polyphyletic.

In the following text, we categorized all observed populations from SP into five groups corresponding to the phylogenetic clusters $\mathrm{A}-\mathrm{D}$ and the cluster "Myochrotes" (of which we have no strains; the main morphological features of all clusters are summarized also in Table 3). Where available, these groups are based on a combination of phylogenetic clustering and morphological markers; species that could not be sequenced were classified to the individual groups based solely on their morphological similarity. Group A involves part of Scytonema-taxa (S. guyanense, $S$. javanicum), which could be assigned to the typical subgenus Scytonema (morphologically and genetically close to S. hofmannii, Fig. 1, A). Group B is another special cluster, including species similar to $S$. hyalinum ( $S$. arcangelii, $S$. ocellatum), as follows from the combined morphological and phylogenetic analyses (Fig. 1B). Group $\mathrm{C}$ is the next phylogenetically separated cluster of Scytonema-like morphotypes (Fig. 1C), containing species with more or less cylindrical filaments, relatively thick sheaths and constricted cylindrical trichomes with cells always distinctly shorter than wide (cluster of S. crispum, S. stuposum and S. bohneri). One of the sequenced strains, Scytonema schmidtii CCIBt 3568 (Fig. 1D), seems to cluster separately from all remaining members of the genus (group D). All four mentioned Scytonema-clusters (and corresponding morphotypes) are recognizable in our samples. Remaining three populations corresponding to the subgenus Myochrotes are not in the phylogenetic tree, since no representative strain was isolated. The members of the genus Brasilonema from SP region were described recently in papers of FIORE et al. (2007) and SAnt'Anna et al. (2011). We have not studied populations morphologically corresponding to the traditional genus Petalonema.

\section{Morphological descriptions}

\section{Group A: Subg. Scytonema}

\section{Scytonema guyanense [MONTAGNE] BORNET et Flahault 1887 (Fig. 2)}

One of the most common tropical Scytonema-species, widely distributed and probably with pantropical distribution. There are also a few records from the temperate zone, but usually lacking satisfactory documentation; all these data are problematic and should be revised. The substantial variability is connected with the wide distribution and existence of several subspecific taxa. The correct area of distribution of this species and the variability of the genotype could be solved only by detailed molecular analyses of populations from different tropical regions with simultaneous morphological examination. Characteristic species of the soil surface (common on wet lateritic soils), less frequently occurs on other subaerophytic substrates (stones, rocks and wood). - Quite common in Brazil. We have studied seven, morphologically almost identical populations from different localities near Cantareira, from other different places of Mata Atlântica, and from the vicinity of Rio Preto (Santa Maria) in the NW of the SP State. All our populations possessed very similar morphology.

Description of our material: Mats on wet soils and rocks, common. Filaments slightly flexuous and entangled, cylindrical, with rarely solitary, mostly binary false branches, which soon divaricate one from another, $14-21 \mu \mathrm{m}$ wide. Sheaths firm, relatively thin or slightly thickened (especially in old filaments), laminated, yellow-brown. Trichomes cylindrical and more or less of the same width along the whole length, not or slightly constricted at cross walls, cylindrical up to the ends, (9)11-13(15) $\mu \mathrm{m}$ wide. Cells in trichomes cylindrical and \pm isodiametric or slightly longer or shorter than wide, but towards the ends clearly shortened and forming terminal meristematic zones. Hormogonia composed of 3-12 cells, liberate from the end of filaments often in series. Heterocytes intercalary, usually solitary, hemispherical, short barrel-shaped, up to cylindrical and up to $2 \times$ longer than wide, $8-24 \times$ $11-15 \mu \mathrm{m}$.

\section{Scytonema javanicum [KüTZING] Bornet et Thuret ex Bornet et Flahault 1887 (Fig. 3)}

Species with wide geographic distribution, but known mainly from tropical areas (pantropical distribution). It is sometimes recorded also from temperate zones, but the identity of such various populations from climatically very distant regions was never confirmed and should be studied in future. The records from the temperate regions are also distinctly scarcer (Europe, Japan, N America, temperate S America) and often relate to glasshouses. The species has colorless up to yellow-brown, not distinctly lamellate sheaths, and characteristic, shortly connected bases of branches (parallely arranged). $-S$. javanicum is a typical soil species, inhabiting mainly wet lateritic soils, but occurs also on leaves and on trunks of trees. The few records from aquatic habitats are not well documented and must be considered as mistakes. - In SE Brazil, it is commonly distributed in soil habitats and it forms relatively morphologically unique populations here. Four populations from different localities in Mata Atlântica were used for our analyses, one from the region of Cantareira, two from different localities in Campos de Jordão, and one from Ubatuba. The last one was isolated into a strain CCALA 1006. 


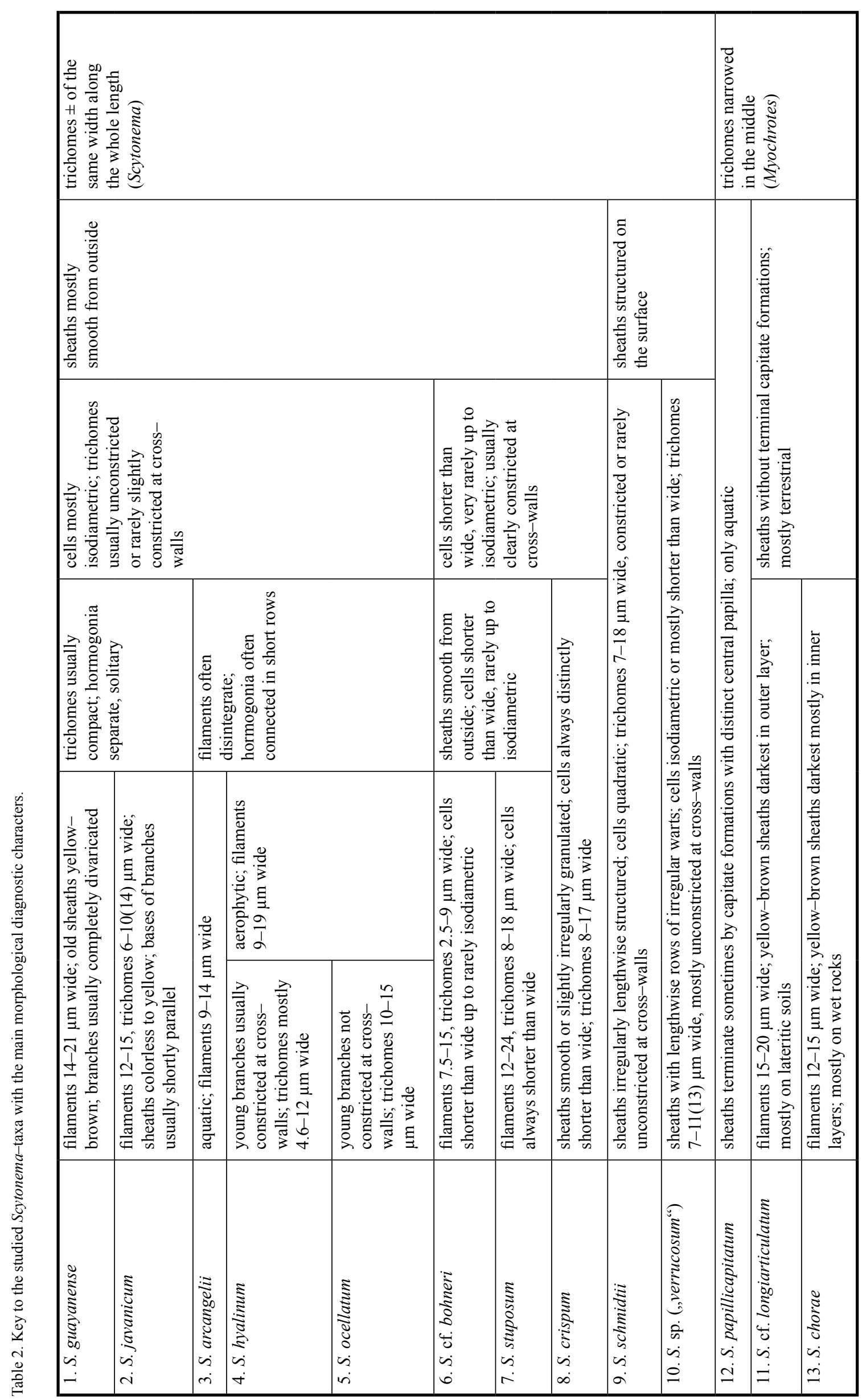




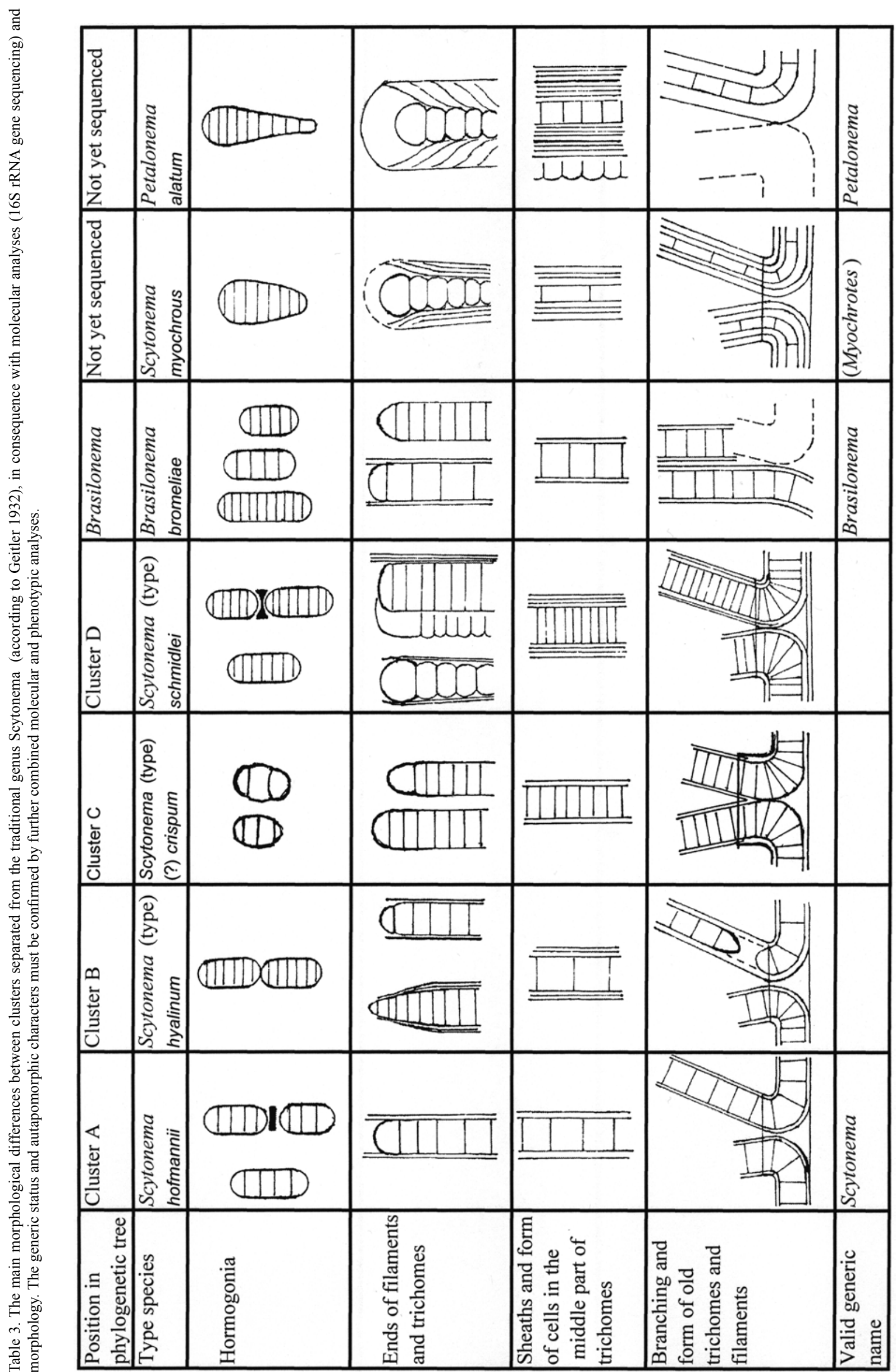




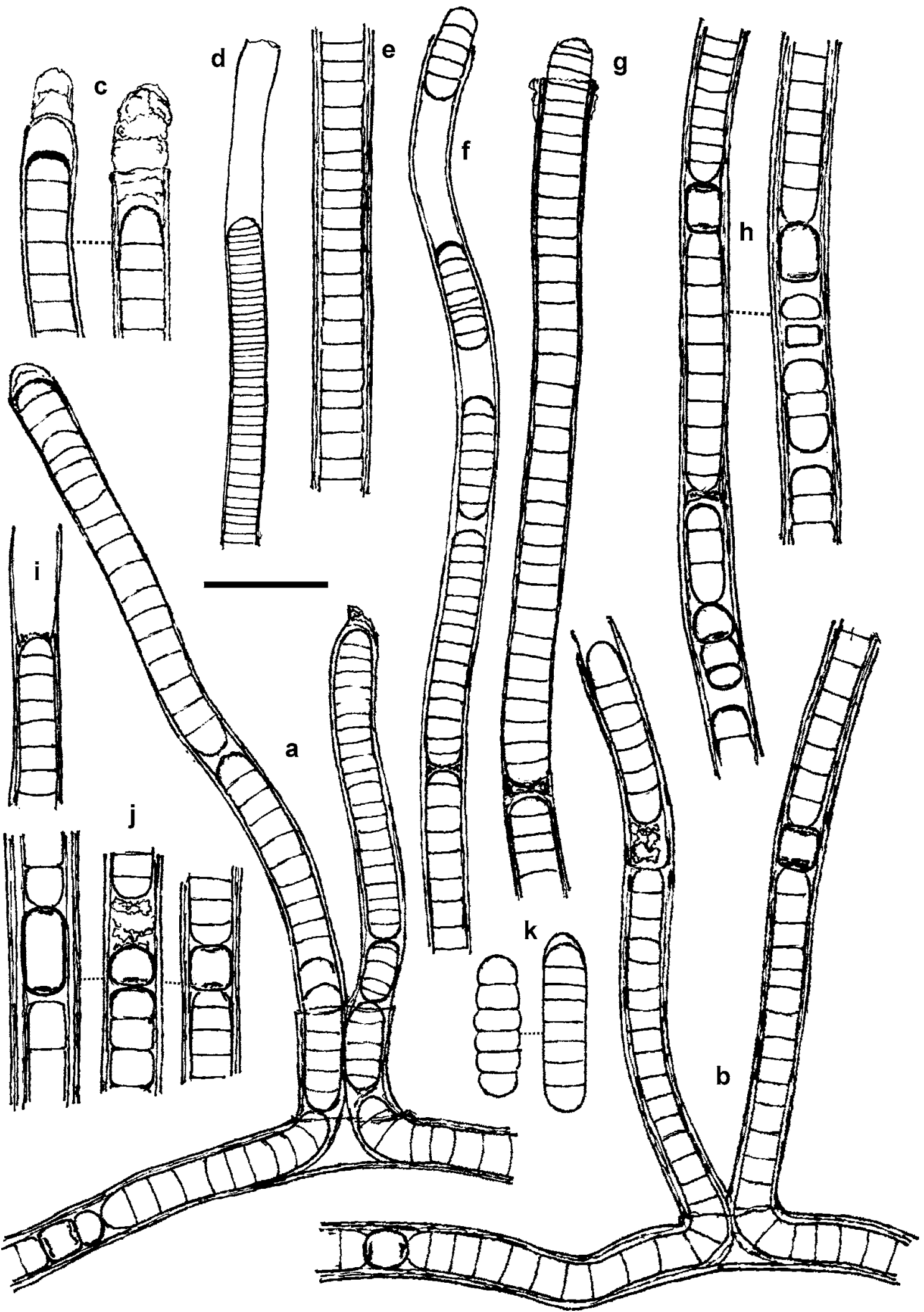

Fig. 2. Scytonema guyanense from natural conditions (Brazil, SP). Scale bar $20 \mu \mathrm{m}$. Orig. 


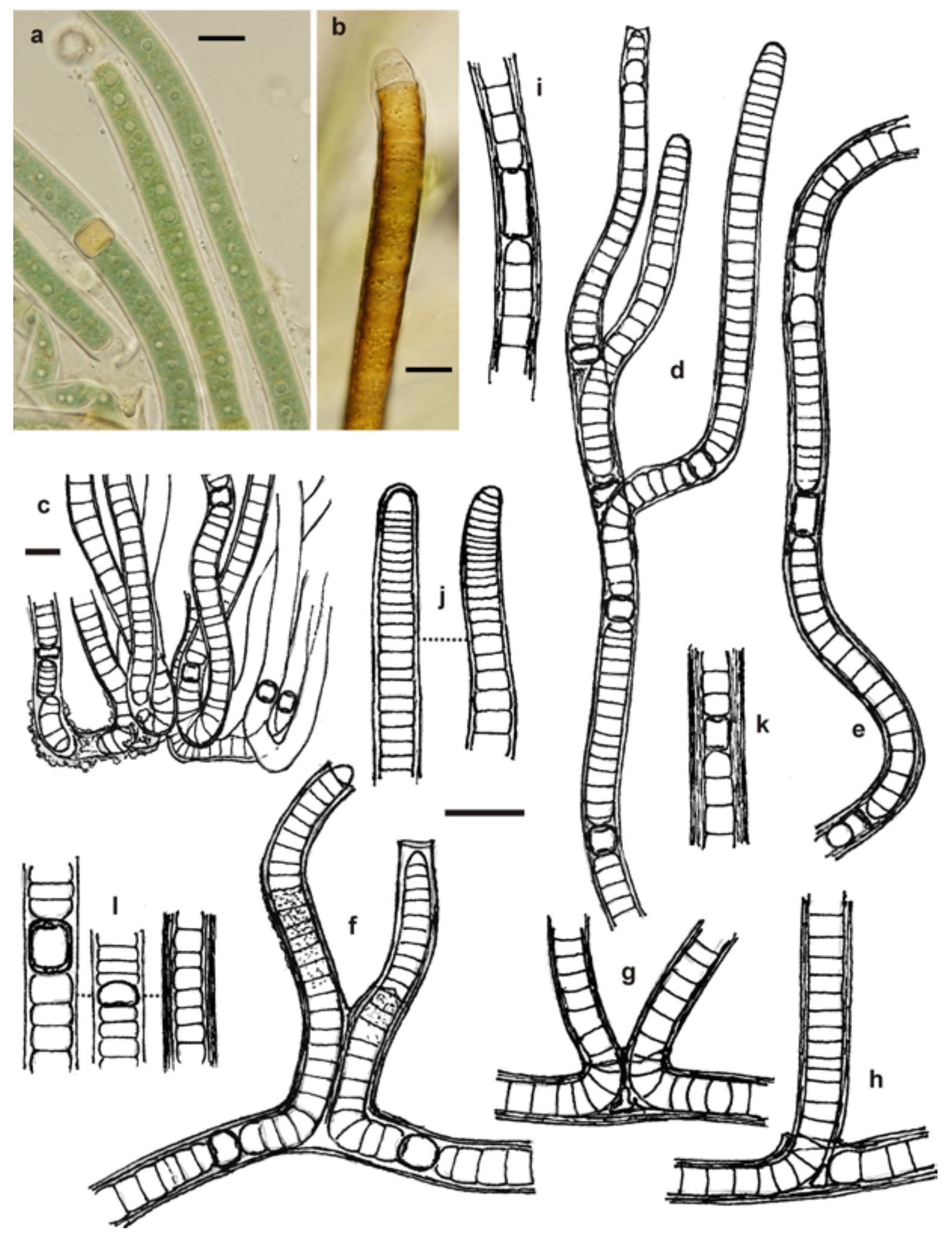

Fig. 3. Scytonema javanicum, line drawings from natural material (Brazil, SP), light micrographs from strain CCALA 1006. Scale bars (a-b) $10 \mu \mathrm{m} ;(\mathrm{c}, \mathrm{d}-1) 20 \mu \mathrm{m}$. Orig. 
Description: Dark mats, mostly on soils, common on wet lateritic substrates in tropical regions, densely entangled together in developed colonies. Filaments cylindrical, with common, especially binary false branchings, sometimes slightly narrowed towards the ends and rounded, usually $12-15 \mu \mathrm{m}$ wide; the binary branches are usually connected parallelly together for a short segment after branching. Sheaths firm, thin to slightly widened, laminated and colorless to yellow, especially in older filaments. Trichomes cylindrical, of the same width along the whole length, not or slightly constricted at cross-walls, usually slightly narrowed and rounded at the ends, $6-10(14) \mu \mathrm{m}$ wide. Cells with green or blue-green content, cylindrical, rarely \pm isodiametric, usually shorter than wide, shortened especially in mostly subterminal meristematic zones. Heterocytes basal or intercalary, solitary, cylindrical or short hemispherical, barrel-shaped, up to cylindrical, mostly \pm isodiametric, less frequently longer than wide, $6-15 \times 8-12 \mu \mathrm{m}$.

\section{Group B: Cluster of ,Scytonema hyalinum“}

\section{Scytonema arcangelii Bornet et Flahault 1887 (Fig. 4)}

A commonly cited species, mainly from tropical regions, particularly known from Central and South Americas. The populations from Africa show some morphological deviations (FrÉmy 1930; SILVA \& PIENAAR 2000). Recorded rarely also from Italy, Japan and North America, but these populations should be revised. - It is an aquatic species, occurs on submerged plants and stones, mostly in stagnant and slowly streaming waters, where it forms up to macroscopically visible clusters. - We have studied one population from the unnamed small lake in the area of the University Federal in Viçosa, Minas Gerais State in detail. This population was isolated in culture (CCIBt 3134, collection of the Botanical Institute, São Paulo) and its 16S rRNA gene was sequenced, confirming its phylogenetic position sister to S. hyalinum (Fig. 1).

Description: Aquatic, thallus in form of floating or sessile clusters. Filaments cylindrical, at the ends not or very rarely slightly widened (only in sheaths), sometimes slightly and shortly narrowed, (9)10 - 13(14) $\mu \mathrm{m}$ wide. Sheaths thin, firm, colorless. Trichomes cylindrical, not or very slightly constricted at cross walls (higher magnifications!), $\pm 10 \mu \mathrm{m}$ wide, at the ends up to $8 \mu \mathrm{m}$ wide, blue-green or greyish green. Cells cylindrical, \pm quadratic, isodiametric or often shorter than wide, especially at the ends of branches; narrower cells particularly in the terminal parts of branches. Terminal cells widely rounded, or slightly narrowed and rounded. Meristematic zones occur rarely at the ends of branches, hormogonia liberate singly. Heterocytes shortly oval or cylindrical with rounded ends, very short up to $2 \times$ longer than wide, of the same width as trichomes.

\section{Scytonema hyalinum GARDNER 1927 (Fig. 5)}

S. hyalinum was described by Gardner from China. It is morphologically and ecologically well characterized, particularly by colorless sheaths, dimensions and numerous necridic cells. The ends of branches are often terminated by cup-shaped formations. This species was later recorded from more places and it seems that it has really wide distribution, especially in tropical Central and S America. However, it is recorded also from desert crusts in $\mathrm{N}$ America, the records from hot springs are probably mistaken. The final position and taxonomic delimitation must be supported by further studies. - According to the description and also according to our results, $S$. hyalinum is a characteristic aerophytic species, growing on periodically wetted rocks, among mosses and in places with detritus. - It occurs in similar localities in Brazil. We have studied in detail the species morphology and variability in samples collected from two localities (rocky and concrete walls) in Mata Atlântica, in the vicinity of Juréia, in Paranapiacaba and one sample form an island of Ilha do Cardoso.

Description: Aerophytic, blackish mats, mostly on stony substrates, less on wet lateritic soils. Filaments relatively densely entangled together, cylindrical, sometimes slightly widened or narrowed at the ends, (9)10-15(18) $\mu \mathrm{m}$ wide; branches often entangled and intensely coiled and crossed. Sheaths firm, thin, only slightly lamellate, colorless, slightly yellowish or brownish only when old. Trichomes cylindrical, sometimes disintegrating and divided in isolated segments, usually not constricted, only short segments of old trichomes constricted at cross walls, of different and variable width along the whole trichome length, 6-12(14) $\mu \mathrm{m}$ wide. Meristematic zones in terminal parts, hormogonia separate sometimes in short rows (up to 8 together), (3-)8-16-celled. Cells barrelshaped to cylindrical, very short in hormogonia and in terminal parts of trichomes, up to isodiametric or rarely slightly longer than wide in middle parts, usually 4.6-8 $\times \pm 9 \mu \mathrm{m}$, greyish-blue or bright blue-green, terminal cells yellowish. Heterocytes cylindrical with rounded ends, shorter than wide up to almost $2 \times$ longer than wide, $5-18 \times 6-12 \mu \mathrm{m}$.

\section{Scytonema ocellatum [Dillwyn] LyNGBYe ex Bornet et Flahault 1887 (Fig. 6)}

An interesting species, supposedly with cosmopolitan distribution, widely cited, but not yet exactly taxonomically defined. It occurs in several morphotypes and several subspecific taxa were described particularly from tropical regions. Majority of the described populations require revision. Typically, trichomes are cylindrical with simple rounded terminal cells and \pm quadratic cells. Sheaths are thin, firstly hyaline, later 
yellow-brown. There is considerable similarity with $S$. javanicum, and both species can be misinterpreted. Especially the character of facultative rough surface of sheaths is problematic; it is not clearly explained and a study was published (TILDEN 1910), where the sheath surface was described as covered with ,detritus particles“. - S. ocellatum forms dark blackish, flat mats on the moist soil, rocks, walls, flower pots and possibly also bark of trees (similarly as e.g. S. guayanense or $S$. javanicum). - In the State of São Paulo, S. ocellatum is widely distributed. We studied five populations from Mata Atlântica, one from the area of Cantareira, and four populations from distant localities in Horto forrestal, Campos de Jordão.

Description: Colonies on wet, mostly lateritic soils, not very common. Filaments slightly flexuous, strictly cylindrical, (10)15-19 $\mu \mathrm{m}$ wide, usually with binary false branching, branches of the same morphology as the main filaments. Sheaths firm, distinct, colorless, yellowish up to yellow-brown, slightly laminated, smooth from outside. Trichomes cylindrical, of the same width along the whole length, mostly $10-15 \mu \mathrm{m}$ wide, not constricted at cross walls, ends not attenuated, end cells rounded. Cells \pm isodiametric or slightly longer or shorter than wide, usually 6-15 $\mu \mathrm{m}$ wide, greyish-blue, only in terminal parts and in hormogonia distinctly shortened. Hormogonia cylindrical, with short cells, 8-18-celled. Heterocytes hemispherical to barrel-shaped up to cylindrical with rounded ends, intercalary, solitary, mostly $8-12 \times 8-15 \mu \mathrm{m}$.

\section{Group C: Cluster of "Scytonema crispum"}

\section{Scytonema cf. bohneri SchMidLe 1902 (Fig. 7)}

$S$. bohneri is an exclusively tropical species and is known mostly from aquatic localities, mainly from stony and rocky streams. It is described from Africa (Cameroon), but known also from tropical Asia (India, Myanmar), Seychelles Islands and from Brazil. Rare reports from temperate areas are not well documented and relate probably to other species. Also our specimens do not correspond exactly to the characteristics of this species, mainly in ecology. We have studied two populations from Mata Atlântica, both from aerophytic habitats (Paranapiacaba, coll. from a wet concrete wall; Campos de Jordão, coll. from bark of trees). Both of these populations correspond morphologically well with the description of $S$. bohneri, but they differ slightly by colored, yellow sheaths, and by ecology. A little different concept of S.bohneri was suggested by STARMACH (1975) from Seychelles Islands ( \pm isodiametrical cells, widened trichomes towards ends).

Description: Mats on wet soils and rocks, less frequently on wet wooden substrates. Filaments nearly straight to flexuous, with mostly binary false branchings, sometimes slightly widened or narrowed toward the ends, (7.5)10-12(15) $\mu \mathrm{m}$ wide. Sheaths slightly thickened, with \pm parallel layers, yellowish or yellow-brown with colorless ends; often with inner yellow-brown layer, outside almost colorless. Trichomes cylindrical, sometimes slightly narrowed in various parts, not or distinctly constricted at cross walls, especially in old trichomes, short segments sometimes distinctly constricted and composed of barrel-shaped cells, (2.5)4.8-6(9) $\mu \mathrm{m}$ wide. Meristematic zones terminal or subterminal. Cells mostly cylindrical, usually shorter than wide (sometimes only $3 \mu \mathrm{m}$ long) rarely up to isodiametric and sometimes in old parts of trichomes long cylindrical, up to $1.8 \times$ longer than wide, blue-green. Heterocytes intercalary, solitary or very rarely in pairs, mostly cylindrical or short barrelshaped, rarely rounded or hemispherical, (4)6-10 $\times$ 5-8.5 $\mu \mathrm{m}$.

\section{Scytonema stuposum [Kützing] Bornet ex Bornet et Flahault 1887 (Fig. 8)}

A species commonly distributed over tropical regions, considered to have pantropical distribution. It is recorded also from regions with mediterranean climate and from warmer areas within temperate zones. In $\mathrm{S}$ America, it probably belongs to the commonest species. It has quite characteristic morphology; the cylindrical filaments, colourless and relatively thin sheaths (to $4 \mu \mathrm{m}$ thick), trichomes constricted at cross-walls and short cells belong to the main diagnostic characters. Terminal cells are usually larger, yellowish and rounded. S. stuposum is aerophytic and subaerophytic, occurs on wet soils, on rocks and among mosses. - It was recorded several times from Brazil (SANT'AnNA \& al. 1978, 1983, 1991; SENNA \& Ferreira 1987; SANT'AnNa 1988, and others). We have had the opportunity to study two strains, CCALA 1008 and CCALA 1009, isolated from aerial localities in Ubatuba, São Paulo. Their position in the phylogenetic tree was confirmed by molecular 16S rRNA gene sequencing (Fig. 1).

Description: Colony flat spreading, dark green; in old cultures forms greyish or brownish mats. Filaments short, densely arranged, single or double false branched, 12-20(24) $\mu \mathrm{m}$ wide. Sheaths colourless, thin, attached or up to $4 \mu \mathrm{m}$ wide, unstructured, closed at the trichome ends. Trichomes distinctly irregularly constricted at cross-walls, wider in the middle part and slighly tapered towards the ends, $8-18 \mu \mathrm{m}$ wide. Cells blue-green or green, finely granulated, cylindrical to disc-like or irregularly compressed, shorter than wide, 2-6 $\mu \mathrm{m}$ long; incomplete cross-walls in meristematic zones distinctly visible. End cells rounded or slightly conical, green-tan coloured; a row of cells at the growing ends usually distinctly constricted (later released as hormogonia?). Heterocytes abundant, single or in pairs, mostly cylindrical, intercalary, beige 

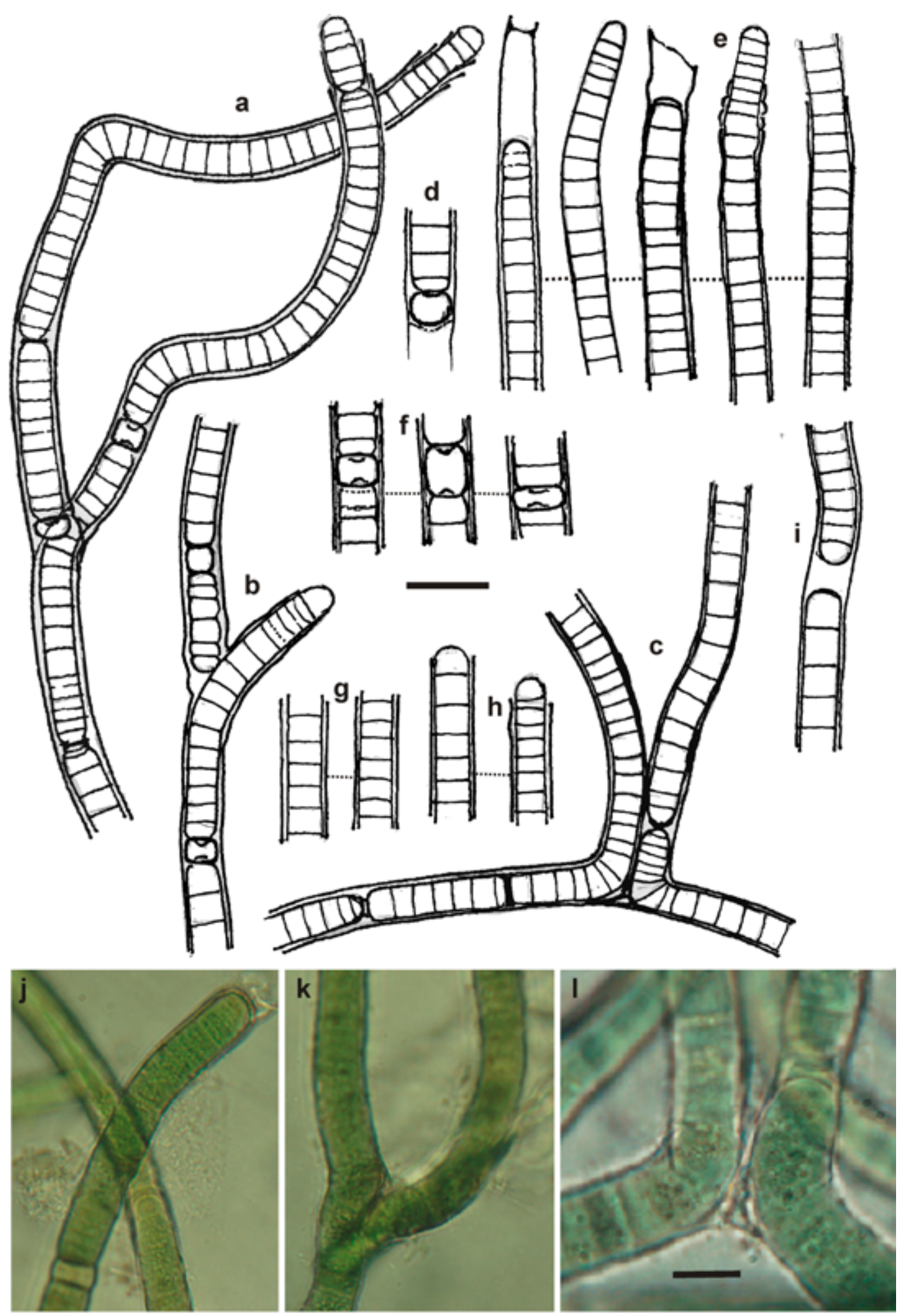

Fig. 4. Scytonema arcangelii (strain CCIBt 3134) from culture conditions. Scale bars (a-k) $20 \mu \mathrm{m}$; (1) $10 \mu \mathrm{m}$. Orig. 


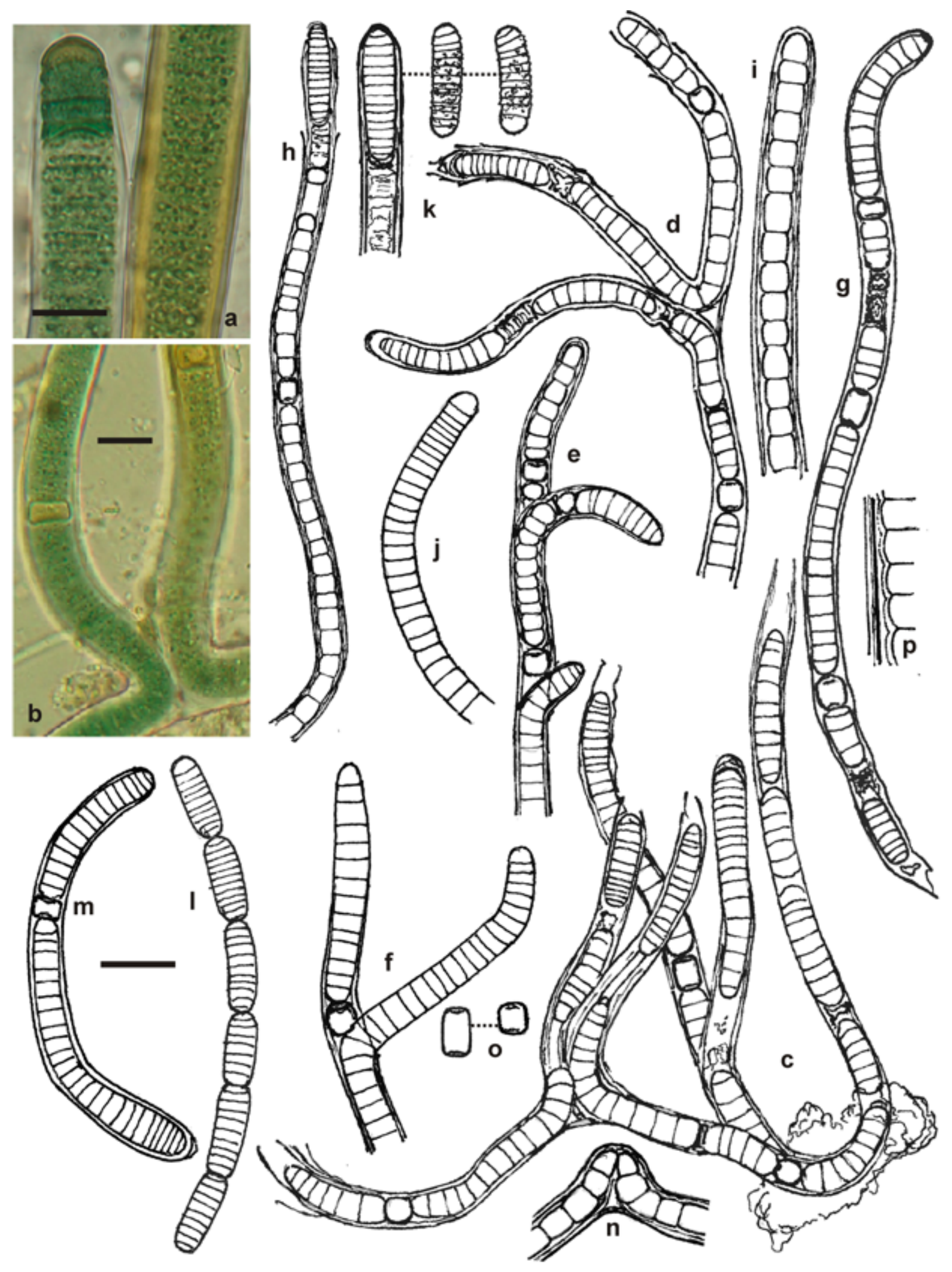

Fig. 5. Scytonema hyalinum from natural material (Brazil, SP). Scale bars (a-b) $10 \mu \mathrm{m}$; (c-o) $20 \mu \mathrm{m}$. Orig. 
to yellow, with sap vesicle, $4-10 \times 10-15 \mu \mathrm{m}$. Necridic cells and hormogonia present.

\section{Scytonema crispum [AgARdh] BoRnet 1889 (Fig. 9)}

This primarily aquatic species is probably quite common in Brazil, but we studied only one strain, CCALA 1007, isolated from aerial localities in Ubatuba, São Paulo. The distribution of this species, which was described from Europe, is considered cosmopolitan (with exception of subpolar regions). However, the species is variable and different populations, corresponding more or less to the original description, should be compared by genetic methods. The dimensions of our specimen (e.g. trichome width) were near the lower size limit for $S$. crispum, which was previously reported in several populations of this taxon described from South America (e.g. MontoyA et al. 1998 from Peru, but isolated from desert soils). This fact might imply that the populations found in $\mathrm{S}$ America belong to different, previously not described taxon.

Description (mainly from isolated cultures): Colonies crumbly, velvet-like, dark green. Filaments short to long, isopolar, easily fragmentating, in shorter parts, singly or binarily false-branched. Trichomes cylindrical, sometimes slightly narrowed towards both ends and towards ends of branches, constricted at cross-walls, with distinct necridic cells, (8)10-17 $\mu \mathrm{m}$ wide. Sheaths relatively thick, colorless to yellow, orange to brownish, smooth or finely granulated at the surface, slightly and sometimes indistinctly lamellated, closed at the ends. Cells inside coarsely granulated, blue-green, usually shorter than wide, barrel-shaped to disc-like, 2-10 $\mu \mathrm{m}$ long; end cells widely rounded. Heterocytes solitary, yellow-green, of various shape, abundant, intercalary or basal (branches), of the same width as vegetative cells, usually flattened (shorter than wide). Common reproduction by hormogonia consisting of $1-8$ cells.

\section{Group D: cluster of "Scytonema schmidtii"}

\section{Scytonema schmidtii Gomont 1901 (Fig. 10)}

Scytonema schmidtii is an old described species, which is, however, up to now little known and recorded in different concepts. The unclear description follows also from the fact that the usually known documentation (a later drawing of FRÉMY 1930 from Africa) is very schematic and does not illustrate the variability and main characters of this species well. The characteristic morphology of the cells, constrictions at cross-walls, characteristic terminal parts of branches and the sheath morphology seem to be typical for this taxon. The sheath is relatively thin, but later slightly thickened, yellowbrown, laminated and closed in young branches, open after hormogonia release. In old, thickened sheaths characteristic lengthwise irregular striation on the surface (see Fig. 9), unusual in other species, was found. - The species grows on aerophytic localities and occurs usually among other algae and cyanobacteria on wet soils, rocks and bark of trees in humid forests. It has evidently only tropical distribution; it was described from Africa, but recorded also from S and SE Asia, New Caledonia and Brazil. There is also a report of the occurrence in marine habitat in Mozambique (SILVA \& PIENAAR 1997), but it seems to be very unusual for this species and probably doubtful. - We studied material from two distant localities, from the area of Botanical Garden in São Paulo from concrete walls covered with mosses and other cyanobacteria in Ilha do Cardoso; we isolated a strain CCIBt 3568 of this species.

Description: Thallus in form of mats on stony and concrete substrates and wet soils. Filaments cylindrical, relatively short, slightly flexuous, with simple or binary false branchings, (8)13-15(25) $\mu \mathrm{m}$ wide. Branches usually divaricate soon one from another, more or less of the same morphology as the main filaments. Sheaths firstly thin, later thickened, laminated, yellowbrown, often more dark in outer layers, from outside lengthwise rugulose. Trichomes cylindrical, not constricted or constricted at cross-walls; constricted particularly at the ends (with very short cells), 7-12(18) $\mu \mathrm{m}$ wide. Meristematic zones terminal, hormogonia liberate from the ends of branches, usually solitary, 4-10-celled. Cells in old trichomes \pm isodiametric, in branches and especially at the ends shortened, end cells rounded. Heterocytes mostly intercalary, \pm of the same width like the trichome, short oval, hemispherical, barrel-shaped, usually shorter, rarely slightly longer than wide.

Notes: It seems that there is a wide variability in dimensions of the otherwise very similar morphological types collected from various localities. We have found populations with different variation in width of filaments and trichomes (up to 45 $\mu \mathrm{m})$, but with other characters almost identical (morphology of trichomes, terminal cells, sheaths, heterocytes etc.) (Fig. 11). It seems that all these populations are closely related one to another, but the correctness of this hypothesis must be supported by molecular analyses. For instance, a similar type (particularly in the special morphology of sheaths) was found in specimens from mats of periodically wetted rocks in Mata Atlântica near Bertioga. The main differences from typical S. schmidtii were found only in quantitative markers, particularly in the greater width of filaments and trichomes, less frequent and less intense constrictions at cross walls and more distinct, laminated and more intensely coloured sheaths. The intense surface striation of the sheaths occurred distinctly in the whole population, also in young filaments and branches. It was not possible to decide, if it belongs into the range of variability of $S$. schmidtii, or if this type represents a specific taxon. The description of this population follows. 


\section{Scytonema sp. (Fig. 12)}

In Mata Atlântica in Campos de Jordão (Horto Forrestal) on bark of trees, populations of Scytonema like cyanobacteria, not identifiable according to existing literature and identification keys, were found. It is probably an up to now unknown Scytonema species, but we were not able to isolate it in a culture and the amount of the material available is insufficient for a proper taxonomic description. The main characters of this species are the always colorless, relatively thick and in outer layers irregularly laminated sheaths, which are on the surface ornamented by a dense rows of small, colorless warts, evidently composed of the same material as the sheaths. Also the ecology seems to be restricted only in the epiphytic habitat on stems of trees and possibly other wooden substrates. The variability of this taxon and especially the curious morphology of sheaths need further studies.

Description: Thallus in form of mats on bark of trees. Filaments cylindrical, binary false branches usually rare, branches divaricate soon one from another. Filaments and branches \pm straight, slightly curved or rarely sligthly flexuous, 15-17(18) $\mu \mathrm{m}$ wide. Sheaths relatively thick, colorless up to slightly yellowish, slightly lamellated and on the surface sculptured by lengthwise, densely arranged lines of small, irregular verrucae. Trichomes cylindrical up to the ends, not constricted at cross walls, only in few segments slightly constricted, 7-11(13) $\mu \mathrm{m}$ wide. Cells cylindrical, usually shorter than wide, rarely up to isodiametric, blue-green, terminal cells widely rounded. Heterocytes solitary, intercalary, usually \pm barrel-shaped up to rounded cylindrical, rarely slightly longer than wide, 7-10(12) $\mu \mathrm{m}$ broad.

\section{Group E: subg. Myochrotes (not sequenced)}

\section{Scytonema cf. longiarticulatum GARDNER 1927 (Fig. 14)}

Originally described from rocks (aerophytic) in Puerto Rico. It is characterized by relatively thick, laminated and partly yellowish sheaths, and by very narrow trichomes with cylindrical, long cells and continually widened terminal parts. Our population is a little different from the original description. The cells in central trichomes are not so long as described by Gardner. There is also wider variability in constrictions at cross walls between the cells and in formation of meristematic parts and hormogonia in apical parts. However, both populations are morphologically and ecologically similar in such a degree, that they can belong to the same genotype. - In Brazil (SP), it grows mostly in lateritic soils, our studied material was collected in Jureia (SP 427936).

Description: Clusters of filaments on wet rocks and lateritic soils. Filaments cylindrical, slightly flexuous, rounded at the ends, 15-20 $\mu \mathrm{m}$ wide, usually with binary false branches. Sheaths thick, laminated, yellow-brown, darkest in outer layers, rough from outside. Trichomes cylindrical, narrow in the middle and $\pm 5 \mu \mathrm{m}$ wide, gradually widened towards the ends, up to $11 \mu \mathrm{m}$ wide at the ends, slightly constricted at cross-walls. Meristematic zones terminal. Cells in middle narrow parts long cylindrical, up to $3 \times$ longer than wide, towards the ends shortened, \pm isodiametric up to very short at the ends; terminal cells often yellowish. Heterocytes intercalary, solitary, usually wider than trichomes, very polymorphic, hemispherical, cylindrical.

\section{Scytonema papillicapitatum SANT'ANNA et} KoMÁreK sp. nov. (Fig. 13)

A morphotype similar to $S$. longiarticulatum from the Myochrotes section, i.e. with narrow middle part of trichomes. This delicate and fine species occurs as more or less monospecific submersed clusters in aquatic localities, and have several characteristic features, such as a sheath with pale yellow coloration in the inner layers (outer layers are colorless) and occasional development of mucilaginous cup-shaped, hemispherical formation with one central prominent calyptra at the ends of the filaments with fingerlike projection (characteristic for this species). This formation is not present in the whole population and occurs only locally, but it is very distinct. The apices of the thick sheaths can be terminated also by other morphological modifications. Because we did not found a similar morphotype in literature, we describe this taxon as a new species. - Aquatic up to subaerophytic species, which was collected in the lake Lagoa de Jacaré (type locality), Mogi Guaçu, sample SP 188495.

Description: Clusters of filaments. Filaments cylindrical, flexuous, sometimes slightly, continually widened towards ends, $13-16 \mu \mathrm{m}$ wide; well developed filaments have hemispherical, cup-shaped cellwall formation with terminal, finger-like processus. False branching relatively rare, usually with two branches (binary branching). Sheaths thick, slightly lengthwise laminated (particularly in old parts), yellow (mostly only internal layers of sheaths), rarely up to brownish. Trichomes thin, 2-3 $\mu \mathrm{m}$ thick, with long cells, not or very slightly constricted at cross-walls, widened towards the ends, 5-7(8) $\mu \mathrm{m}$ wide, usually distinctly constricted. Meristematic zones terminal or subterminal, usually with constrictions at the crosswalls. Cells in older trichomes long cylindrical, up to $5 \times$ longer than wide, in terminal parts distinctly shortened, cylindrical to barrel-shaped, up to 2-3x shorter than wide. Heterocytes intercalary, solitary, sometimes slightly wider than trichomes, cylindrical, $10-15 \times 6-6.5 \mu \mathrm{m}$. 
Diagnosis: Strato pannoso, tomentoso, viridi, cum filis paucim tortuosis intricatis. Filamenta cylindrica, flexuosa, praecipue paucim vel distincte et gradatim dilatata ad apices, 13-16 um lata, pseudo-ramosa. Vaginis latis, longitudinem lamellosis, luteis (praecipue in partes internis), rare ad fuscis. Ramificatio rara, plerumque cum ramis binis. Trichoma tenues, 2-3 $\mu \mathrm{m}$ lata, cum cellulis longis, ad dissepimenta not vel paucim constricta, ad apices dilatata, ad 5-8 $\mu \mathrm{m}$ lata, distincte constricta. Partes meristematicae terminales vel subterminales. Cellulae cylindricae in trichomatibus adulties, ad $5 \times$ longior quam latae, in partes terminalibus curtae, cylindricae vel barriliformes, ad 2-3× brevior quam latae, cellula apicalis saepe cum calyptra membranosa, cum papilla cetrali externa. Heterocytae intercalares, solitariae,

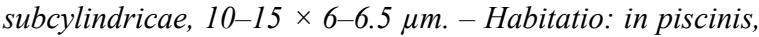
stagnis, paludibusque cum plantis aquaticis natans, vel subaerophytice; locus classicus: lacus Lagoa de Jacaré, Mogi Guaçu, provincia São Paulo, Brasilia. - Typus: SP 188495, deposited in Herbarium of the Institute of Botany in São Paulo, Brazil.

\section{Scytonema chorae SANT'ANNA et KoMÁREK sp. nov. (Fig. 15)}

This morphotype is similar to the previous ones, but with characteristic morphology, from aerophytic localities (granitic rocks). This species also shows the diacritical features of Myochrotes, but is distinct by thick lamellated sheaths which are mostly closed at the apex and together with widened trichome form slightly club-shaped rounded ends. The striation is distinct through the layers with changing intensity of the yellow or yellow brown and brown coloration. The layers of the sheath are sometimes fan-like widened towards the ends (inside of the sheath). The dimensions are very uniform and one of the characteristical features are cylindrical heterocytes, usually 2-times wider than vegetative cells. Because this species was impossible to fit into any previously described species (particularly in respect to morphology of filaments and trichomes) and because we had an opportunity to study its populations with the same morphology and ecology from two distant localities, we describe it as a new species. Its name was selected according to the name of characteristic locality. - We studied intensely two populations of this species from stony walls in the region of Cantareira, from the Gruta que Chora near Ubatuba (type locality) and from State Park of Ilha do Cardoso.

Description: Subaerophytic mats on stones. Filaments cylindrical, slightly continually club-shaped, widened towards ends, with rare binary false branching, slightly flexuous, $12-14 \mu \mathrm{m}$, towards the ends up to $15 \mu \mathrm{m}$ wide. Sheaths thick, firm, distinctly laminated with layers, at the ends funnel-like divaricated (inside the outer sheath margin), yellow-brown to brown, especially in inner layers. Trichomes in the middle parts cylindrical, thin, not constricted at cross-walls, 3-4 $\mu \mathrm{m}$ wide, at the ends club-shaped widened with shortened cells, up to $8-9 \mu \mathrm{m}$ wide. Meristematic zones \pm terminal. Cells in middle filaments long cylindrical, up to $3 \times$ longer than wide, up to $15 \mu \mathrm{m}$ long, at the terminal parts short cylindrical, up to distinctly shorter than wide. End cells rounded to conical-rounded. Heterocytes distinctly wider than neighboring vegetative cells, intercalary, solitary, relatively rare, mostly short up to long cylindrical, to $8 \times 5-6 \mu \mathrm{m}$.

Diagnosis: Strata epilithica, pannosa. Filamenta cylindrica, flexuousa, paucim gradatim dilatata ad apices ad paucim clavata, 12-14 $\mu \mathrm{m}$, ad apices ad $15 \mu \mathrm{m}$ lata, rare pseudoramosa. Vaginis latis, firmis, distincte lamellosis, lamellis divergentibus in partes apicalis, luteo-fuscis vel fuscis, praecipue in partes internis. Rami longi, filamentis principalibus similares. Trichoma tenues et cylindricae in partes adultis, ad dissepimenta not constricta, 3-4 $\mu \mathrm{m}$ lata, ad apices paucim clavata. Partes meristematicae, plus minusve terminales. Cellulae cylindricae, longae, ad $3 x$ longior quam latae, ad $15 \mu \mathrm{m}$ longae, in partes terminalibus curtae, ad brevior quam latae; cellula apicalis rotundata vel conice-rotundata. Heterocytae distincte latior quam cellulae vegetativae, solitariae, intercalares, plus minusve cylindricae ad 8 × 5-6 $\mu \mathrm{m}$. - Habitatio: Subaerophytice ad rupes humidas; locus classicus: caverna Gruta que Chora dicta, prope oppido Ubatuba, provincia São Paulo, Brasilia. - Typus: SP 427934 deposited in Herbarium of the Institute of Botany in São Paulo, Brazil.

\section{Discussion}

The genus Scytonema is an important component of microphyte communities in terrestrial (aerophytic) habitats, particularly in tropical regions. Many species seem to have pantropical distribution, but the populations from various distant regions need taxonomic revision and their areas of distribution must be checked. The molecular determination of different populations must be preferred in taxonomic evaluation of the samples, but the precise reassessment of their morphology and study of life cycles is still an essential part of the modern polyphasic analyses. Relatively broad diversity of Scytonema-like types over the tropical countries was documented in numerous articles (e.g. Gardner 1927; SkUja 1949; DesiKachary 1959; SAnt'Anna 1978; Couté et al. 1999, and others). These records need comparative analysis and further revision according to the modern criteria, both molecular and morphological, before a new taxonomic system can be accomplished.

The revision of the populations belonging to the traditional genus Scytonema in tropical regions and their taxonomic evaluation according to the currently accepted criteria must be therefore based on determination of phylogenetic relationships between various populations and taxa, which usually results in recognition of a wider diversity of genera and species. This complex study and reorganization of the old system was already started. The genus Brasilonema, 


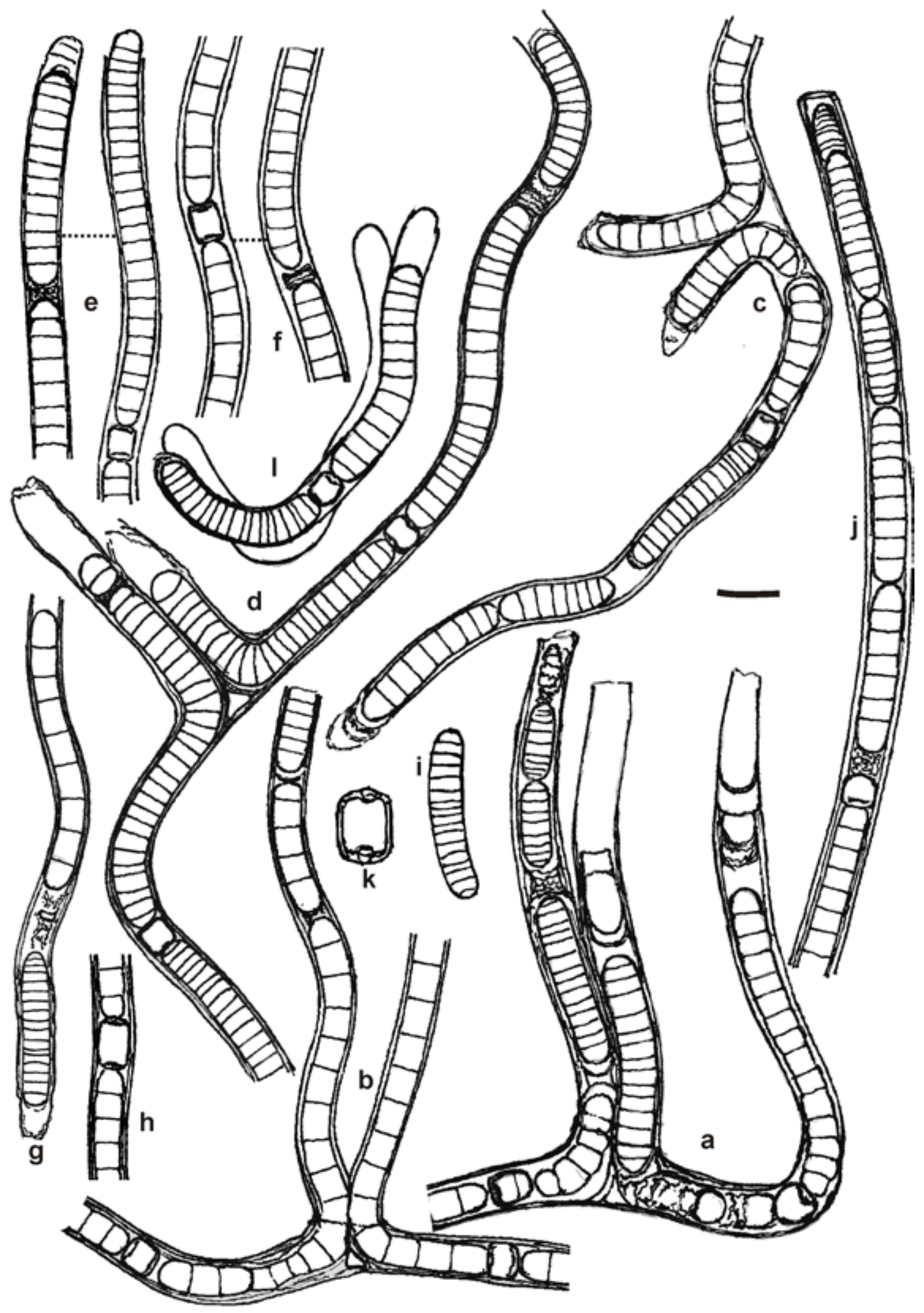

Fig. 6. Scytonema ocellatum from natural material (Brazil, SP). Scale bar (a-i) $20 \mu \mathrm{m}$. Orig. 


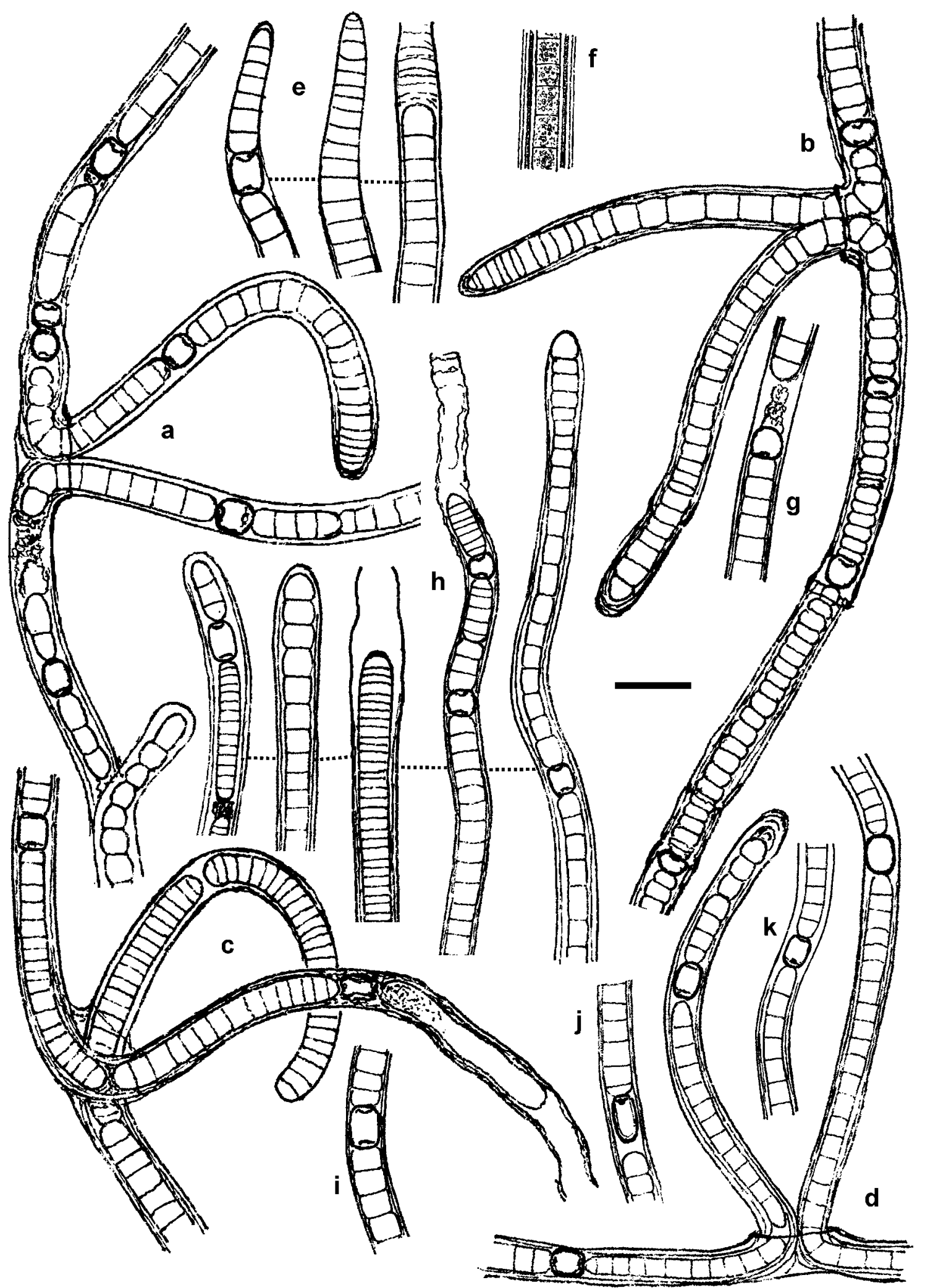

Fig. 7. Scytonema cf. bohneri from natural material (Brazil, SP). Scale bar $20 \mu \mathrm{m}$. Orig. 


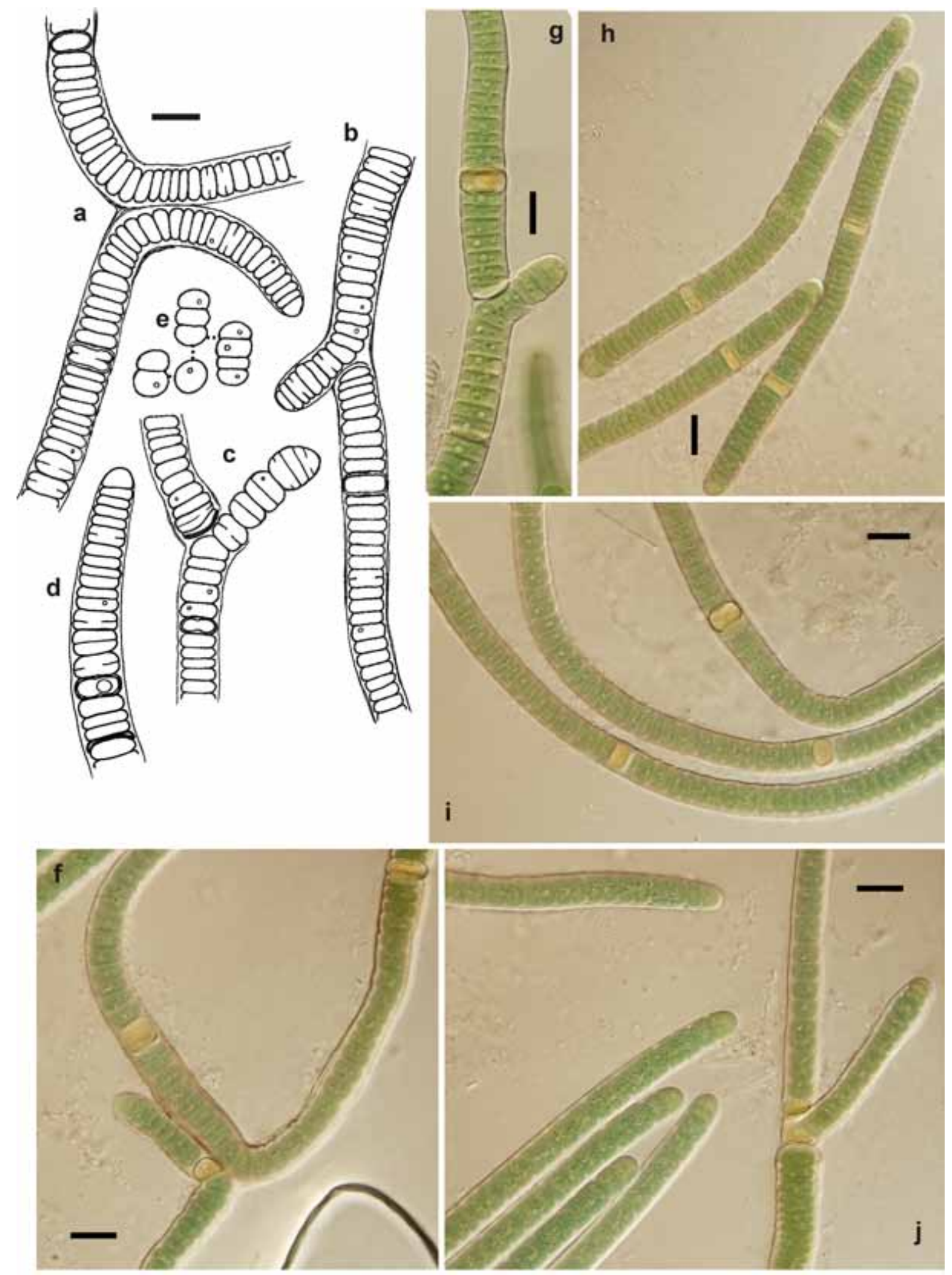

Fig. 8. Scytonema stuposum from cultures CCALA 1008 and CCALA 1009. Scale bars $20 \mu \mathrm{m}$. Orig. 


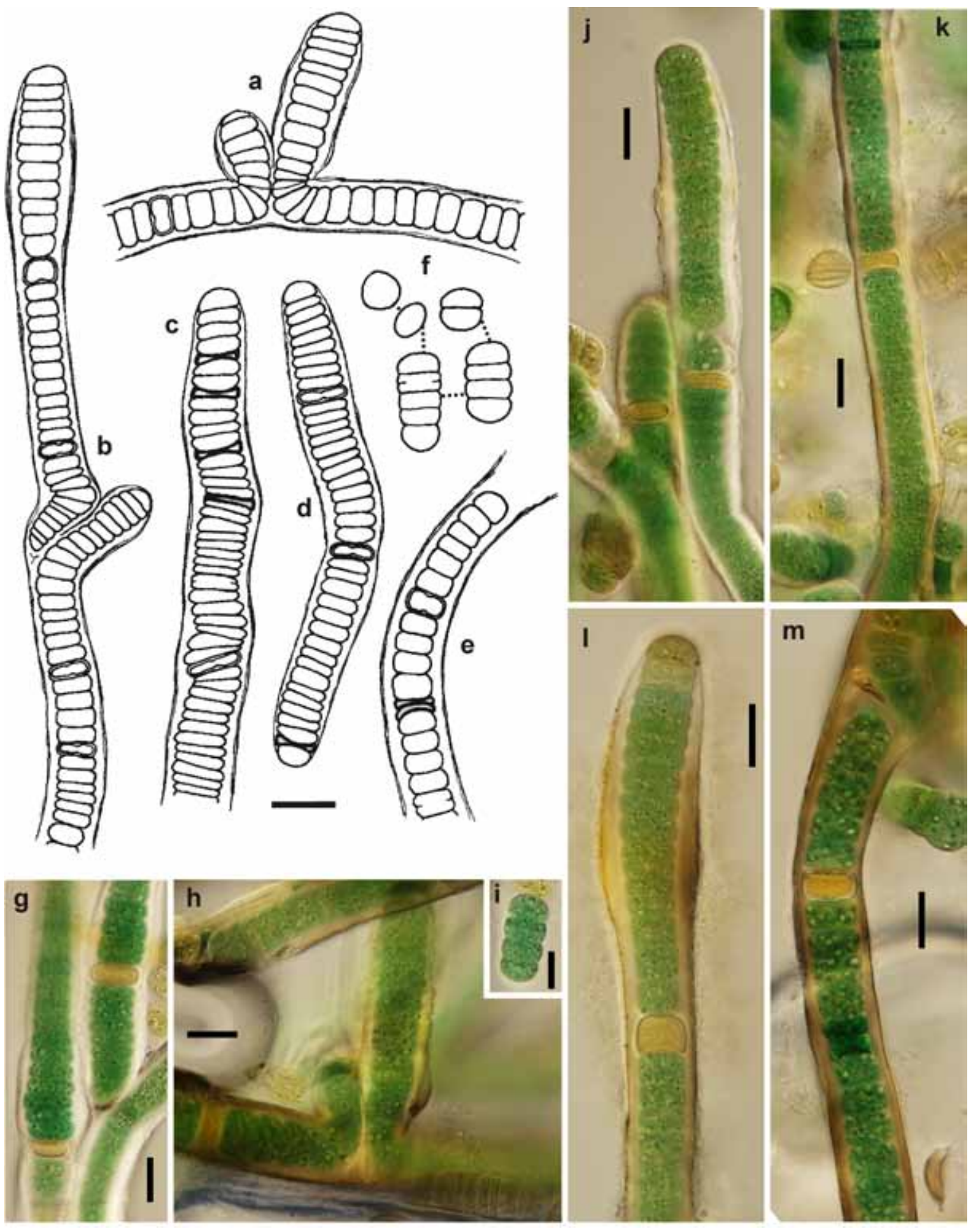

Fig. 9. Scytonema crispum from cultured material (Brazil, SP), strain CCALA 1007. Scale bars $20 \mu \mathrm{m}$. Orig. 


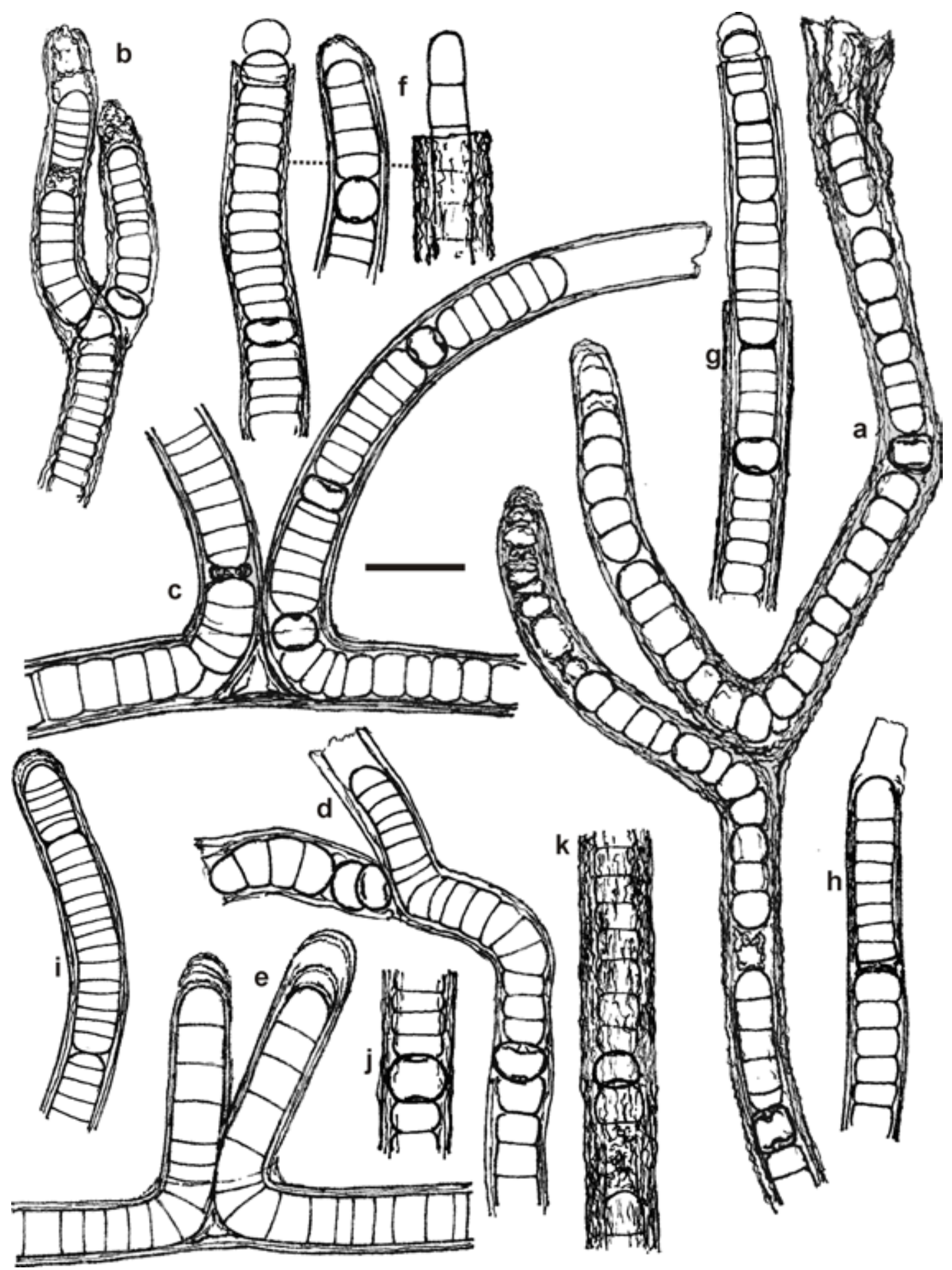

Fig. 10. Scytonema schmidtii from the culture (strain CCIBt 3568). Scale bar $20 \mu \mathrm{m}$. Orig. 

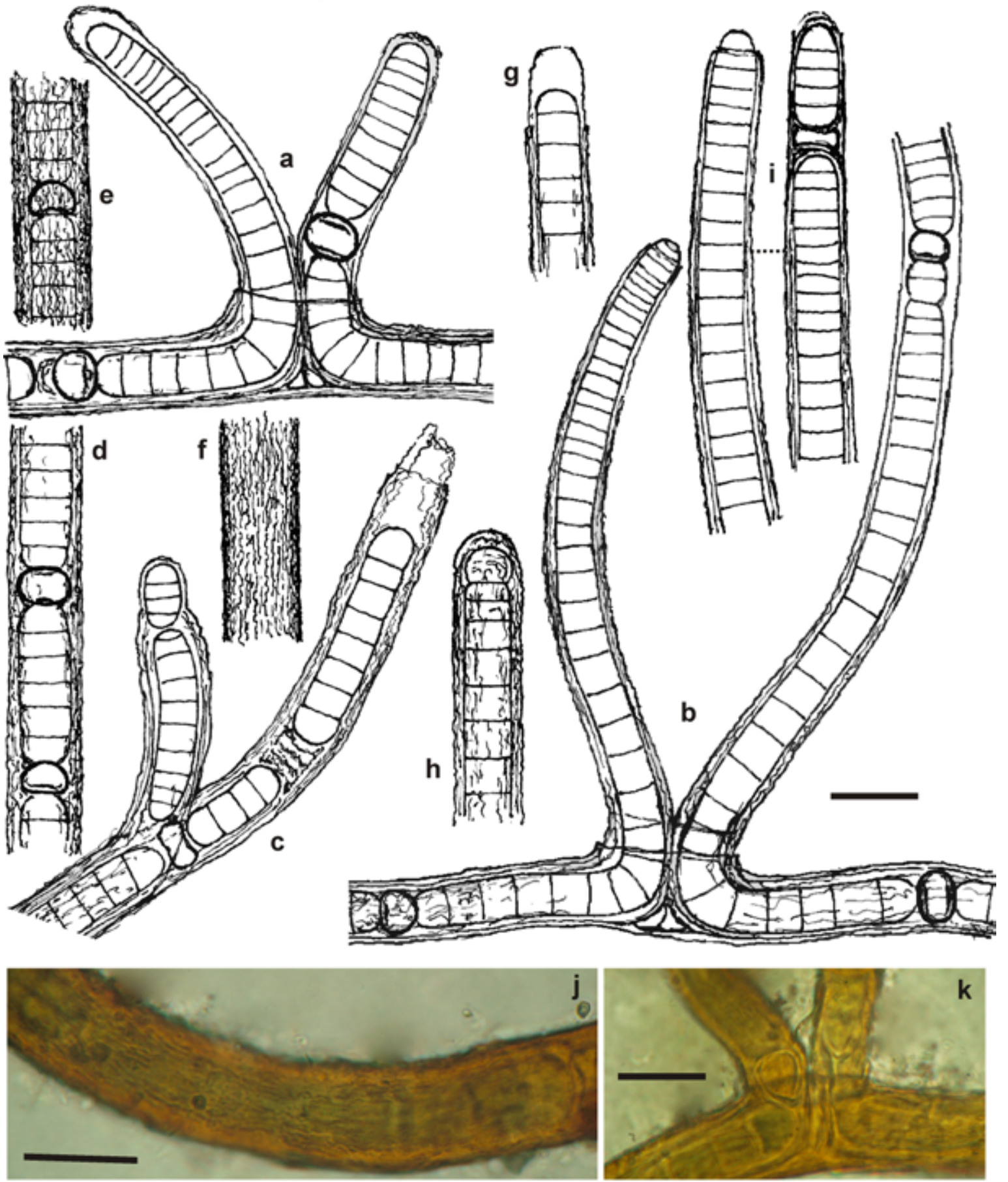

Fig. 11. Scytonema cf. schmidtii from natural material (Brazil, SP). Scale bars $40 \mu \mathrm{m}$.

close to the traditional genus Scytonema (FIORE et al. 2007; Aguiar et al. 2008; SAnt' AnNA et al. 2011; VACCARINO \& JoHANSEN 2012; BECERRA-ABSALÓN et al. 2013) was recently defined. Further separation and definition of several other generic units from this cluster, which are distinguishable genetically and phenotypically, are expected (Fig. 1, Table 3).

The species included in our paper do not represent the whole diversity of the scytonematacean vegetation neither from Brazil, nor from São Paulo State (cf. Senna \& Ferreira 1987; SAnt'Anna
1988; SENNA 1994). Büdel et al. (2002) recorded Scytonema myochrous and S. ocellatum from the epilithic cyanobacterial communities of Inselbergs in the Atlantic Rainforest in eastern Brazil. However, we tried to describe precisely most common selected populations in respect to modern taxonomic concepts of the traditional genus Scytonema sensu lato, although the examination of natural variability of Scytonema populations was not easy. The great diversity of habitats in tropical ecosystems favored the development of numerous differently modified populations and this 


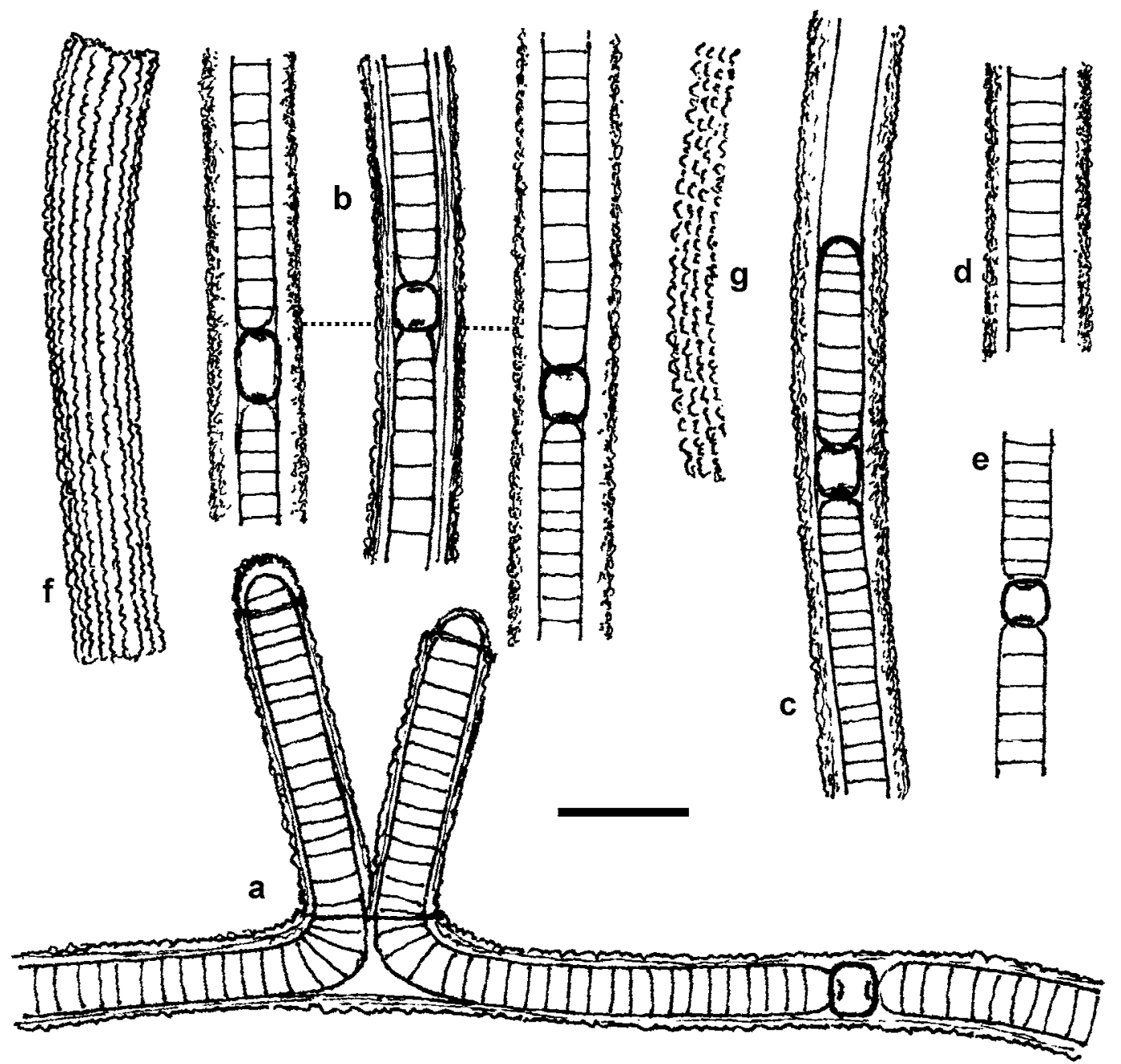

Fig. 12. Scytonema sp. ("verrucosum") from natural material (from bark of trees in Campos de Jordão, Mata Atlântica; Brazil, SP); $g=$ detail of outside sculpture of a sheath. Scale bar (a-f) $20 \mu \mathrm{m}$. Orig.

diversity made then difficult to find two quite identical populations or strains from the same species (i. e. genetically uniform clusters).

The molecular evaluation of the species within the genus Scytonema is essential, but the limits in variation of different morphological markers are important for the common knowledge of such cyanobacterial species as well. We present therefore in this article our phenotypical analysis of several dominant Scytonema populations from Atlantic Rainforest in SE Brazil. Separation of the traditional genus Scytonema in different clusters, which probably represent separate genera according to the modern classification criteria for cyanobacteria (JOHANSEN \& CASAMATta 2005; KomÁreK 2010) is continually being confirmed just by molecular sequencing. All the up to now recognized clusters (A, B, C, D), which follow from the phylogenetic tree (based on our own strains and strains included in GenBank), are morphologically recognizable, their autapomorphic characters can be defined and they can be designated as different morphotypes (BoHUNICKÁ et al. 2012). Members of all four mentioned clusters (morphotypes) were identified during our studies in Brazil primarily according to the morphological markers. The following phenotypic markers are characteristic for Scytonema groups, studied in this paper:

(1) Group A: It contains the type species of the genus Scytonema, S. hofmannii. The characteristic features are (i) cylindrical filaments and cylindrical trichomes of the same width along the whole length up to the ends, (ii) firm and slightly lamellated, but relatively thin, colorless or yellowish sheaths, (iii) \pm quadratic cells in old trichomes, and (iv) terminal cells are widely rounded at the ends and do not differ distinctly from other vegetative cells. From our samples, $S$. guyanense and $S$. javanicum belong to this morphotype.

(2) Group B: Contains three species (S. arcangelii, $S$. hyalinum, S. ocellatum) with colorless, firm sheaths, usually indistinctly narrowed trichomes in the middle parts, mostly not constricted at cross-walls, and with tendency to fragmentation in shorter segments of trichomes. In our populations characteristical 

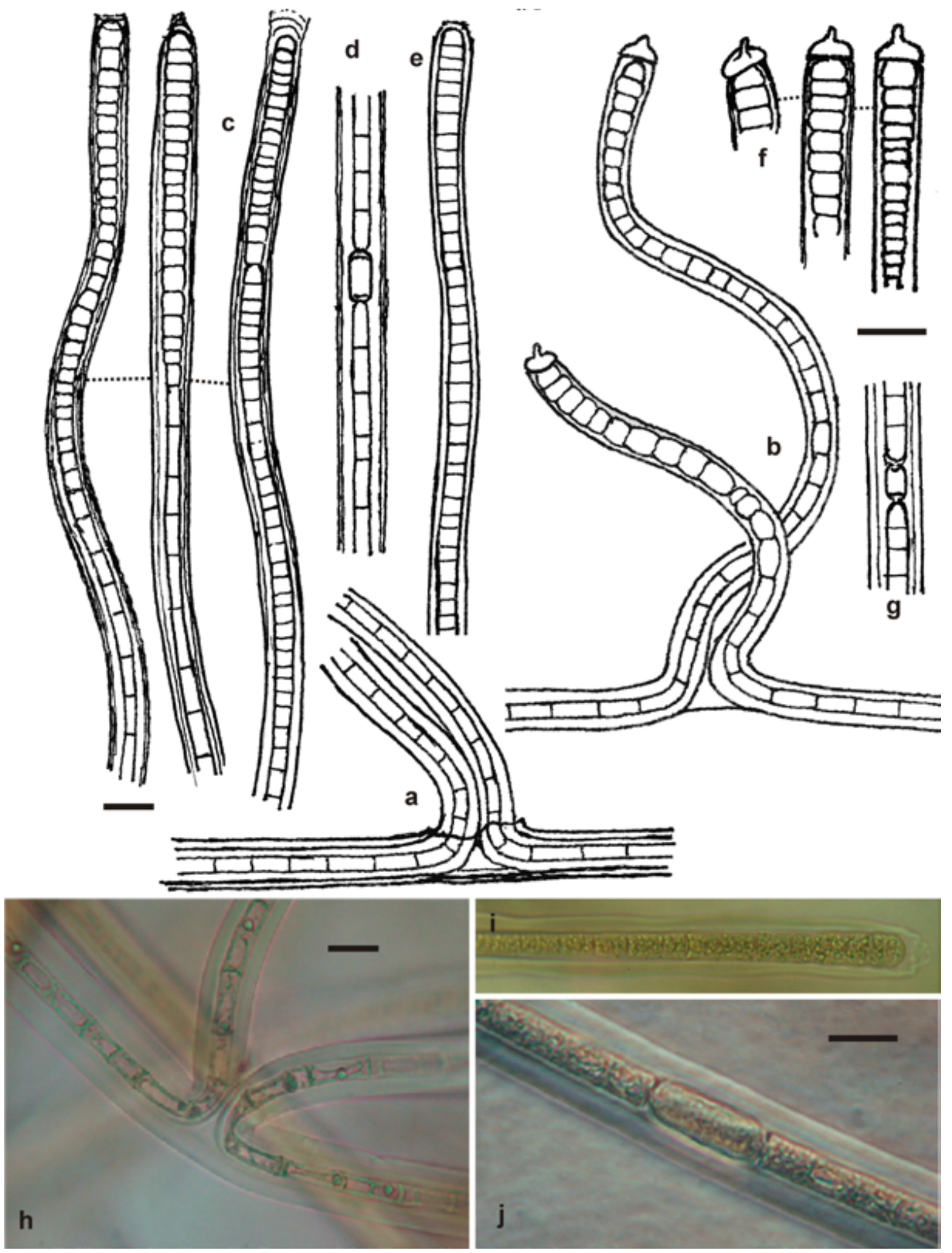

Fig. 13. Scytonema (Myochrotes) papillicapitatum from natural material (aquatic, from lake Lagoa de Jacaré, Moji Giuani; Brazil, SP); from type material (SP 188495). Scale bars $20 \mu \mathrm{m}$. Orig. 


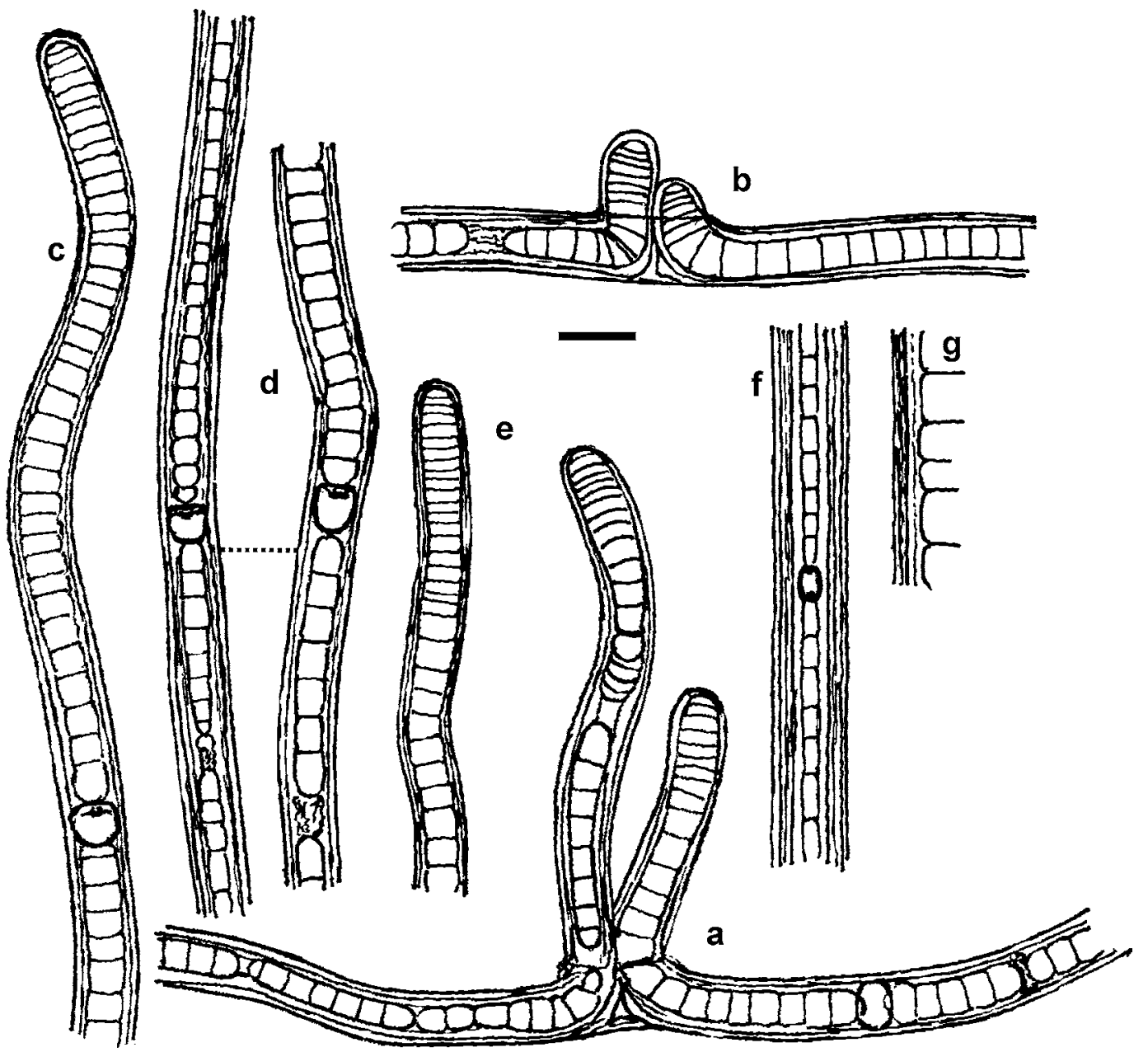

Fig. 14. Scytonema (Myochrotes) cf. longiarticulatum from natural material (lateritic soils in Jureia; Brazil, SP); (g) detail of a sheath. Scale bar $20 \mu \mathrm{m}$. Orig.

terminal meristematic zones were observed, resulting in two or more separated hormogonia with short cells, developing often in rows. Terminal cells are widely rounded.

(3) Group C: Included populations have mostly relatively thick, cylindrical filaments and trichomes, not narrowed in the middle and not distinctly widened at the ends, often constricted (facultatively) at crosswalls. The trichomes are composed only of relatively uniform short cells, usually distinctly shorter than wide, rarely up to isodiametric in short segments. Sheaths are firm, thickened, lamellate and often structured from outside when old, frequently of yellow-brown color. Terminal cells in developed filaments are usually little longer than vegetative cells, up to isodiametric or longer than wide and remarkably yellowish. Based on morphology, S. crispum, S. millei and S. polycystum belong to this cluster; of our materials we assigned $S$. bohneri, S. stuposum and S. crispum to this group.

(4) Group D: This cluster is represented mostly by S. schmidtii, which is, however, very variable and forms several slightly different types, the taxonomic evaluation of which is not clear. The thickened, laminated, yellow-brown and from outside usually rugulose sheaths belong to the main characters of this group. Cells are mostly isodiametric in old trichomes and short in terminal parts of branches.

(5) The morphotype of Myochrotes (with the type species $S$. myochrous) was not yet sequenced. However, this cluster is distinctly phenotypically different from the typical Scytonema and was classified as a separate subgenus or section already by old authors. The trichomes are clearly narrowed in the middle (older) parts, usually with distinctly long (often to $2-4 \times$ longer than wide), narrow and cylindrical cells; the cells are shortened and widened only in terminal parts, up to shortly barrel-shaped form. Sheaths are firm, wide, lamellate and often colored (yellow-brown). They resemble therefore rather the genus Petalonema. We never have found $S$. myochrous in the material of São Paulo State, but $S$. cf. longiarticulatum and the two new species $S$. chorae and S. papillicapitatum from the same subgenus were registered in our aquatic, epilithic and soil samples.

Our results must be further checked and confirmed 


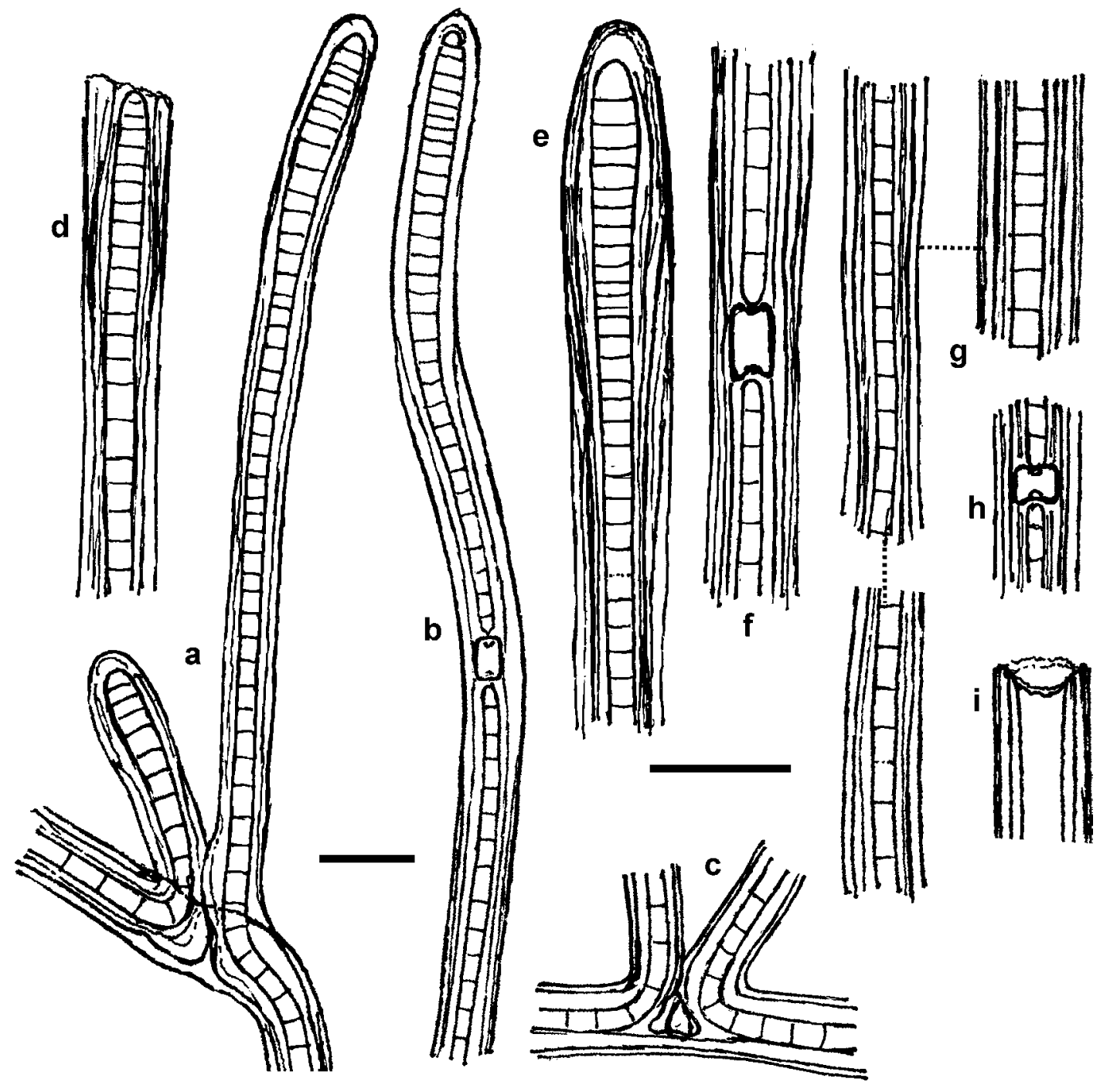

Fig. 15. Scytonema (Myochrotes) chorae from natural material (aerophytic, Gruta que Chora near Ubatuba; Brazil, SP); type material (SP 427934). Scale bars $20 \mu \mathrm{m}$. Orig.

by more comprehensive molecular analysis in future studies, and folowed by a decisive taxonomical and nomenclatural revision. Especially, the relatively small number of sequenced taxa, and the use of a single molecular marker (16S rRNA gene) did not provide convincing statistical support for higher phylogenetic clustering. A multi-locus evolutionary reconstruction of a wider selection of scytonematacean strains is in progress and should soon bring a better picture of the actual taxonomy within this family of cyanobacteria. However, for now, the detailed phenotypic analyses indicate the probable conformity of revised morphological characters with natural clusters, following from the recent phylogenetic analyses (Table 3). Our results also yield further contribution to the ecological significance and phytogeographical distribution of important terrestrial cyanobacteria in tropical and subtropical regions.
ACKnowledgments

The study was realized under the support of FAPESP (Process 11/51642), CNPq (Process 158353/2010-2), (Sant'Anna, Hentschke, Rigonato, Fiore), and of the grants GAČR P506/12/1818 and KONTAKT II LH 12100 (Komárek, Mareš, Bohunická). The authors acknowledge the Willi Hennig Society for sponsoring the freely available TNT software. The access to computing and storage facilities owned by parties and projects contributing to the National Grid Infrastructure MetaCentrum, provided under the programme "Projects of Large Infrastructure for Research, Development, and Innovations" (LM2010005) is highly appreciated. We are particularly thankful to Tomáš Hauer for consultations and to Dana Švehlová for technical assistance. This study was supported as a long-term research development project no. RVO 67985939.

\section{REFERENCES}

Aguiar, R.; Fiore, M.F.; Franco, M.W.; Ventrella, M.C.; Lorenzi, A.S.; Vanetti, C.A. \& Alfenas, A.C. (2008): A novel epiphytic cyanobacterial species from the genus Brasilonema causing damage to Eucalyptus leaves. - J. Phycol. 44: 1322-1334. 
Becerra-Absalón, I.; Rodarte, B.; Osorio, K.; Alba-Lois, L.; Segal-Kischinevzky, C. \& Montejano, G. (2013): A new species of Brasilonema (Scytonemataceae, Cyanoprokaryota) from Tolantongo, Hidalgo, Central Mexico. - Fottea 13: 25-38.

Berrendero, E.; Perona, E. \& Mateo, P. (2008): Genetic and morphological characterization of Rivularia and Calothrix (Nostocales, Cyanobacteria) from running water. - Int. J. Syst. Evol. Microbiol. 58: 447-460.

BoHUNICKÁ, M.; MAREŠ, J. \& KOMÁREK, J. (2012): Comparison of the molecular and morphological diversity within the family Scytonemataceae (Nostocales, Cyanobacteria). - In: Abstract Book of 14 International Symposium on Phototrophic Prokaryotes (ISPP 2012). - p. 61, Porto, Portugal.

Bourrelly, P. (1970): Les algues d'eau douce. III. - 512 pp., N. Boubée \& Cie., Paris.

Boyer, S.L.; Flechtner, V.R. \& Johansen, J.R. (2001): Is the $16 \mathrm{~S}-23 \mathrm{~S}$ rRNA internal transcribed spacer (ITS) region a good tool for use in molecular systematics and population genetics? A case study in cyanobacteria. - Mol. Biol. Evol. 18: 1057-69.

Boyer, S.L.; Johansen, J. R.; Flechtner, V. R. \& Howard, G. L. (2002): Phylogeny and genetic variance in terrestrial Microcoleus (Cyanophyceae) species based on sequence analysis of the 16S rRNA gene and associated 16S-23S ITS region. - J. Phycol. 38: 1222-1235.

Büdel, B.; Weber, H.-M.; Porembski, S. \& Barthlott, W. (2002): Cyanobacteria of Inselbergs in the Atlantic Rain Forest zone of eastern Brazil. - Phycologia 41: 498-506.

Couté, A.; Tell, G. \& Thérézien, Y. (1999): Cyanophyceae (Cyanobacteria) aérophiles de Nouvelle-Calédonie. Cryptogamie/Algologie 20: 301-344.

Desikachary, T.V. (1959): Cyanophyta. - In: ICAR Monographs on Algae. - 686 pp., New Delhi.

Drouet, F. (1973): Revision of the Nostocaceae with cylindrical trichomes. - 292 pp., Hafner Press, New York-London.

Fiore, M.F.; Sant'Anna, C.L.; Azevedo, M.T.P.; KomÁreK, J.; KaštovskÝ, J.; SuleK, J. \& LoRENZI, A.S. (2007): The cyanobacterial genus Brasilonema - molecular and phenotype evaluation. - J. Phycol. 43: 789-798.

FrÉMY, P. (1930): Les Myxophycées de l'Afrique équatoriale française. - Arch. Bot. 2: 1-508.

Gardner, N.L. (1927): New Myxophyceae from Porto Rico. - Mem. New York Bot. Garden 7: 1-144.

Geitler, L. (1932): Cyanophyceae. - In Rabenhorst's Kryptogamenflora von Deutschland, Österreich und der Schweiz 14. - 1196 pp., Akad. Verlagsges., Leipzig.

Goloboff, P.; Farris, J. \& Nixon, K. (2008): TNT, a free program for phylogenetic analysis. - Cladistics 24 : 774-786.

Gouy, M.; Guindon, S. \& Gascuel, O. (2010): SeaView version 4: a multiplatform graphical user interface for sequence alignment and phylogenetic tree building. Mol. Biol. Evol. 27: 221-224.

Guindon, S. \& Gascuel, O. (2003): A simple, fast, and accurate algorithm to estimate large phylogenies by maximum likelihood. - Syst. Biol. 52:696-704.

Johansen, J. R. \& CAsamatta, D.A. (2005): Recognizing cyanobacterial diversity through adoption of a new species paradigm. - Algological Studies (Cyanobacterial Research 6) 117: 71-93.
Katoh, K.; Asimenos, G. \& Toh, H. (2009): Multiple alignment of DNA sequences with MAFFT. - In: Posada D. (ed.): Bioinformatics for DNA Sequence Analysis. - pp. 39-64, Humana Press, Totowa, New Jersey.

KomÁrek, J. \& Anagnostidis, K. (1989): Modern approach to the classification system of cyanophytes 4 Nostocales. - Algological Studies 56: 247-345.

KomÁReK, J. (2010): Recent changes (2008) in cyanobacterial taxonomy based on a combination of molecular background with phenotype and ecological consequences (genus and species concept). Hydrobiologia 639: 245-259.

KotaI, J. (1972): Instructions for preparation of modified nutrient solution Z8 for algae. - Norwegian Institute for Water Research, publication B-11/69, Oslo, Blindern.

LI, L.C. (1933): New species and varieties of freshwater algae from China. - The Ohio J. Sci. 33: 151-155.

Myers, N.; Mittermeier, R.A.; MitTermeier, C.G.; DA FonsecA, G.A.B. \& Kent, J. (2000): Biodiversity hotspots for conservation priorities. - Nature 403: 853-858.

Montoya, H.T.; Gómez, J.C.; Medina, D.C. \& Vera, G. (1998): Cultivo de Cianobacterias de costras algalliquémicas de las lomas de Pachacamac, Lima. Biotempo 3: 7-16.

Posada, K. \& Crandall, K.A. (1998). Modeltest: testing the model of DNA substitution. - Bioinformatics 14: 817-818.

Sant'Anna, C.; Pereira, H.A.S.L. \& Bicudo, R.M.T. (1978): Contribuiçao ao conhecimento das cyanophyceae do parque estudual das fontes do Ipiranga, São Paulo, Brazil. - Rev. Brasil. Biol. 38: 321-337.

Sant'anna, C.L.; Azevedo, M.T.P.; Fiore, M.F.; Lorenzi, A.s.; KAŠTOVsKÝ, J. \& KomÁreK, J. (2011): Subgeneric diversity of Brasilonema (Cyanobacteria, Scytonemataceae). - Rev. Brasil Bot. 34: 51-62.

Sant'AnnA, C. L. (1988): Scytonemataceae (Cyanophyceae) from the state of São Paulo, southern Brazil. - Nova Hedwigia 46: 519-539.

Sant'Anna, C. L.; Bicudo, R.M.T. \& Pereira, H.A.S.L. (1983): Nostocophyceae (Cyanophyceae) do Parque Estadual da Ilha do Cardoso, Estado de São Paulo, Brazil. - Rickia 10: 1-27.

Sant'AnNa, C. L.; Silva, S.M.F. \& Branco, L.H.Z. (1991): Cyanophyceae da Gruta-que-Chora, Município de Ubatuba, Estado de São Paulo, Brasil. - Hoehnea 18: 75-97.

SenNA, P.A.C. \& Ferreira, L.V. (1987): Nostocophyceae (Cyanophyceae) da Fazenda Água Limpa, Distrito Federal, Brasil, 2: Famílias Nostocaceae, Scytonemataceae e Stigonemataceae. - Rickia 14: 7-19.

SennA, P.A.C. (1994): Cyanophyceae de la Région Est du District Fédéral, Brésil, 1. - Bull. Jard. Bot. Nat. Belg./ Bull. Nat. Plantentuin Belg. 63: 81-100.

Silva, S.M.F. \& PienaAR, R.N. (2000): Benthic marine Cyanophyceae from Kwa-Zulu Natal, South Africa. - Bibliotheca Phycologica 107: 456 pp.

SkuJA, H. (1949): Süsswasseralgenflora Burmas. - Nova Acta Reg. Soc. Sc. Upsal., Ser. 4, 14: 1-188.

Starmach, K. (1966): Cyanophyta-sinice. - In: Flora slodkowodna Polski 2. - 807 pp, PAN, Państw. Wyd. Nauk., Warszawa. 
Starmach, K. (1975): Algae from montane streams on the Island of Mahé, in the Seychelles. - Acta Hydrobiologica (Kraków) 57: 201-209.

Tilden, J. (1910): Minnesota Algae. The Myxophyceae of North America and adjacent regions including Central America, Greenland, Bermuda, The West Indies and Hawaii. - Bot. Ser. Minneapolis, 8: 1-328.

VAcCarino, M.A. \& Johansen, J.R. (2012): Brasilonema angustatum sp. nov. (Nostocales), a new filamentous cyanobacterial species from the Hawaiian Islands. J. Phycol. 48:1178-1186.

Yilmaz, M.; Phlips, E.J. \& Tillett, D. (2009): Improved methods for the isolation of cyanobacterial DNA from environmental samples. - J. Phycol. 45: 517521.
Zapomělová, E.; Hrouzek, P.; ŘezanKa, T.; Jezberová, J.; ŘehÁKovÁ, K.; Hisem, D. \& KomÁrková, J. (2011): Polyphasic characterization of Dolichospermum spp. and Sphaerospermopsis spp. (Nostocales, Cyanobacteria): Morphology, 16S rRNA gene sequences and fatty acid and secondary metabolite profiles. - J. Phycol. 47: 1152-1163.

C) Czech Phycological Society (2013)

Received March 8, 2013

Accepted April 21, 2013 